\title{
Shareholder Bylaws, Shareholder Nominations, and Poison Pills
}

\author{
Brett H. McDonnell $\dagger$
}

\begin{abstract}
Shareholder bylaws that limit or direct board action raise tough and fascinating questions of both statutory interpretation under state law and an important policy matter. In particular, over the last decade shareholders have sought to use bylaws to limit poison pills and to grant shareholders access to the corporate proxy materials to nominate directors. This paper argues that an expansive, although not unlimited, shareholder power to enact bylaws is both a plausible interpretation of Delaware's statutory scheme and desirable as a policy matter. Shareholder bylaws that set general rules of corporate governance and procedure should be valid unless more specific statutory provisions remove a specific matter from the bylaw power. Applied to poison pill and proxy access bylaws, both are valid under the general analysis, although poison pill bylaws may not be valid due to a more specific provision of Delaware law. The SEC should require boards to include bylaw proposals unless the particular proposal is clearly invalid under relevant state law.
\end{abstract}

\section{TABLE OF CONTENTS}

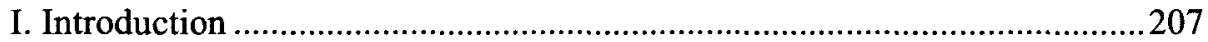

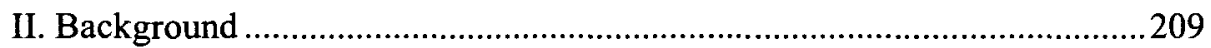

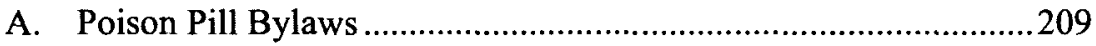

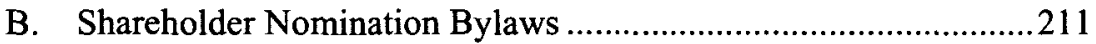

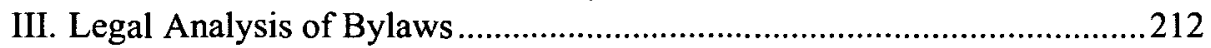

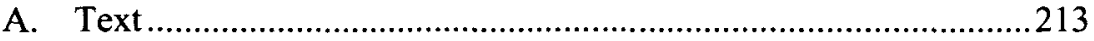

B. Legislative History and Judicial Interpretations .........................227

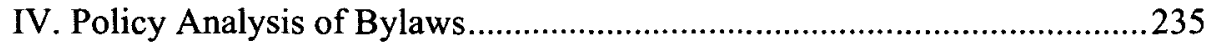

A. Arguments Assuming Shareholder Primacy .............................237

B. Arguments Assuming a Stakeholder Approach ..........................248

\footnotetext{
$\dagger$ Associate Professor, University of Minnesota Law School. I would like to thank Stephen Bainbridge, Lynne Dallas, David McGowan, Frank Partnoy, Paul Rubin, Bill Wang, and participants at the University of Minnesota Law School's Half-Baked Ideas Club, a panel at the Law and Society Association's annual meeting, and faculty colloquia at the University of San Diego Law School and the University of California, Hastings College of the Law for helpful comments. David Youngblood and the LIBR.A service at the University of Minnesota Law School provided helpful research assistance.
} 


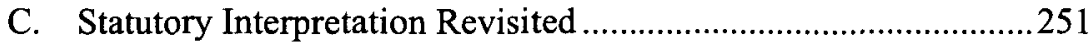

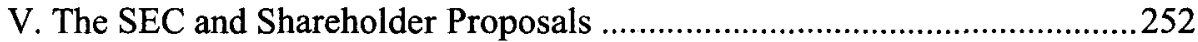

A. Proposals that Are Improper Under State Law ............................253

B. Proposals that Relate to Ordinary Business Operations.................258

C. Proposals that Relate to an Election............................................260

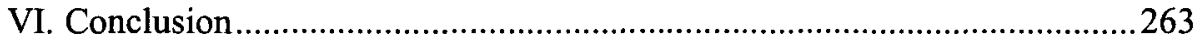




\section{Shareholder Bylaws, Shareholder Nominations, and Poison Pills}

\section{INTRODUCTION}

As large institutional investors own a larger percentage of American public corporations, some of those investors have become more active and have tried to hange corporate governance practices at companies they believe are poorly run. This often has taken the form of shareholder proposals suggesting specific changes.

Although traditionally shareholder proposals under Rule $14 \mathrm{a}-8$ have been mere suggestions, some shareholders have made proposals in the form of bylaws which, if valid, would legally bind boards of directors. Two particularly significant kinds of bylaw proposals have been poison pill and proxy access bylaws. Poison pill bylaws limit the ability of a board to maintain or enact a poison pill, a leading antitakeover defense. Proxy access bylaws allow certain shareholders, under specified circumstances, to have their nominees for director positions included in the corporation's proxy materials. ${ }^{\prime}$

Shareholder bylaws limiting or directing board action raise a tough and fascinating question of statutory interpretation. Every state has a statute allowing shareholders to enact bylaws concerning firm governance, ${ }^{2}$ but every state also has a statute granting the board of directors broad authority to govern the corporation. ${ }^{3}$ Each state also has many more specific corporate governance statutes that grant or do not grant authority to set rules on specific points in bylaws. Resolving the tensions among these statutes is quite hard, and has generated much scholarly debate.

I will engage in a detailed analysis of the many statutory provisions touching on bylaw power, and argue that shareholder bylaws regulating general matters of corporate governance and procedure should be valid under Delaware law, which is typical of most state law on this point. ${ }^{4}$ Applying this analysis to poison pill and proxy access bylaws, both should be valid under the general analysis, although a more particular statute concerning rights and options on

1. For further background on shareholder amendments, particularly poison pill and proxy access bylaws, see infra Part II.

2. See, e.g., DEL. CODE ANN. tit. 8, $\$ 109$ (2005); MOD. Bus. CORP. ACT $\S 10.20$ (a) (1984).

3. See, e.g., DEL. CODE ANN. tit. 8, § 141(a) (2005); MOD. BUS. CORP. ACT § 8.01(b) (1984).

4. The basic position I advocate is close to that set out in John C. Coffee, Jr., The Bylaw Battlefield: Can Institutions Change the Outcome of Corporate Control Contests?, 51 U. MIAMI L. REV. 605 (1997). I provide greater textual support for that position, in response to the leading textual analysis to date of the question, Lawrence A. Hamermesh, Corporate Democracy and Stockholder-Adopted By-Laws: Taking Back the Street?, 73 TUL. L. REV. 409 (1998), which I argue takes an overly narow view of the bylaw power. 
shares creates significant doubt concerning poison pill bylaws. ${ }^{5}$ I further argue that Delaware case law is consistent with this textual analysis of the statutes. ${ }^{6}$

Shareholder bylaws raise tough questions of policy as well as of corporate law. Indeed, the policy and legal issues are inter-related: policy concerns do and should inform judicial decisions, and the case law in turn helps shape our understanding of the relevant policy goals. I will analyze the policy dilemma and conclude that shareholder bylaws regulating corporate governance are desirable. Key to the analysis is noting that the bylaw debate solely concerns how a default rule is set; corporations will be able to vary the rule whichever way courts decide. Thus, if courts hold that the statutes grant shareholders broad power to set corporate governance rules, corporations can limit that power in the certificate of incorporation. Conversely, if courts hold that statutes grant shareholders only narrow bylaw power, corporations can give shareholders greater authority in the certificate. Many thoughtful objections to expansive shareholder power to initiate corporate rules do not apply to a default rule that shareholders and directors can limit if they choose. Within this limited context, a default rule of broad shareholder power to enact bylaws concerning corporate governance is best, given shareholder ability to evaluate such general rules and given the danger of allowing boards to veto attempts to limit their own authority. Moreover, it is easier for corporations to contract around a broad bylaw default rule than a narrow rule, as contracting around the statutory default occurs through amendments to the certificate of incorporation, and only the board (which tends to prefer a narrow bylaw power) has the power to initiate changes to the certificate. ${ }^{?}$

Even if one agrees that expansive bylaw power is both valid under state law and desirable, a practical analysis of shareholder bylaws cannot end there. Favorable state court rules will be worthless to shareholders unless they can use the corporate proxy materials to propose bylaws. Creating and circulating proxy materials of their own is almost always prohibitively expensive unless shareholders are seeking to gain a controlling share block. The SEC's Rule $14 \mathrm{a}-8$ governs when boards are required to include shareholder proposals in the corporation's proxy materials; hence the interpretation of that rule becomes quite important for our subject. Although the SEC staff has wobbled some over time (including recent months), its usual approach has been to allow boards to exclude both poison pill and proxy access bylaws. I argue that both as a matter of corporate governance and as a matter of comity, the SEC should require boards to include both types of bylaw proposals. That approach would allow greater experimentation both among corporations and among states. Indeed, allowing shareholder proxy access bylaws would be a wiser course than

5. See infra Part III.A.

6. See infra Part III.B.

7. See infra Part IV. 
proceeding with the one-size-fits-all proxy access rule that the SEC has proposed amidst great controversy. ${ }^{8}$

\section{BACKGROUND}

The growth of more activist institutional investors over the last few decades $^{9}$ has led to more use of shareholder-passed bylaws as a way to restrain boards or empower shareholders. Bylaws are one of the two main private documents defining a corporation's governance structure and procedure. The certificate (or article, in some states) of incorporation is the other. Institutional investors have looked to amending the bylaws rather than the certificate because although the certificate takes precedence over the bylaws if the two conflict, shareholders alone can amend the bylaws, while only the board has the power to initiate amendments to the certificate, which shareholders must then approve.

Two sets of shareholder campaigns in particular have gained attention. In the nineties shareholders tried to enact bylaws limiting the ability of boards to adopt and maintain poison pills. In the last few years shareholders tried to enact bylaws requiring corporations to include shareholder nominees to the board in the corporate proxy under certain circumstances.

\section{A. Poison Pill Bylaws}

The poison pill is the most potent of antitakeover defenses. If a corporation has a poison pill and a hostile bidder acquires enough of the corporation's shares to trigger the pill, other shareholders will have the right to buy more shares at below-market prices, meaning that the bidder must buy those shares as well. Alternatively, the pill could trigger the right to purchase more shares of the bidder at low prices after a merger has occurred, diluting the value of the bidder's current shareholdings.

Conventional wisdom is that the presence of an unredeemed poison pill makes a takeover prohibitively expensive for the bidder. ${ }^{10} \mathrm{~A}$ bidder may try to elect new board members who will redeem the pill, but a staggered board combined with a prohibition on removing directors without cause means that it will take over a year for such a strategy to succeed. ${ }^{11}$ There is debate over whether blocking hostile bids helps shareholders by increasing the company's

8. See infra Part V.

9. See Bernard Black, Shareholder Passivity Reexamined, 89 MICH. L. REV. 520 (1990); John C. Coffee, Jr., Liquidity Versus Control: The Institutional Investor as Corporate Monitor, 91 COLUM. L. REV. 1277 (1991); Edmund B. Rock, The Logic and (Uncertain) Significance of Institutional Shareholder Activism, 79 GEO. L.J. 445 (1991).

10. See Lucian Bebchuk et al., The Powerful Antitakeover Force of Staggered Boards: Theory, Evidence, and Policy, 54 STAN. L. REV. 887 (2002). But cf. William J. Carney, The Illusory Protections of the Poison Pill, 79 NOTRE DAME L. REV. 179 (2003).

11. See Bebchuk et al., supra note 10. 
ability to bargain for a higher price ${ }^{12}$ or hurts them by allowing the incumbent board to entrench itself. ${ }^{13}$ The latter view predominates among many corporate law scholars. Shareholder activists appear to hold the latter view as well, and thus would like to limit the ability of boards to put and keep pills in place.

Bylaws are about the only way that shareholders can initiate binding actions in corporate policy. Thus, shareholders turned to bylaws as a way to limit poison pills once it became clear that courts were going to allow boards to create and keep in place all but the most powerful of poison pills. In the nineties a growing number of shareholders introduced shareholder proposals that would enact such bylaws. Some bylaws required boards to redeem existing pills under certain circumstances, ${ }^{14}$ while others required shareholder approval for putting new pills in place. ${ }^{15}$ As institutional investors increasingly exercised their voting power, such corporate governance proposals gradually received more favorable votes. There is, however, a considerable question as to whether such poison pill bylaws are valid under state law. Two state courts did consider this issue in the late nineties. The Oklahoma Supreme Court upheld a poison pill bylaw in Int'l Brotherhood of Teamsters General Fund v. Fleming Companies. ${ }^{16}$ A federal district court interpreting Georgia law struck down a poison pill bylaw in Invacare Corp. v. Healthdyne Technologies, Inc. ${ }^{17}$

Right around the time of Fleming, the SEC decided that boards could choose to exclude poison pill bylaws. ${ }^{18}$ To enact a bylaw in a public corporation, shareholders need to obtain the proxy voting power for a majority of the shares voting. Distributing a proxy on one's own is generally prohibitively expensive, costing at minimum in the hundreds of thousands of dollars. Even large institutional investors are not willing to expend that kind of money on corporations in which they own at most only a few percent of the outstanding shares. They will be willing to propose bylaws only if they can do so through the corporation's own proxy solicitation material that it sends to shareholders at the company's expense.

The SEC's rules govern when boards are required to include shareholder proposals in the corporation's proxy materials. Once the SEC decided to allow boards to exclude poison pill bylaws, the chances of such bylaws being proposed and passed fell to essentially zero. That is where things now stand,

12. See, e.g., Marcel Kahan \& Edward B. Rock, Corporate Constitutionalism: Antitakeover Charter Provisions as Pre-Commitment, 152 U. PA. L. REv, 473 (2003).

13. See, e.g., Frank H. Easterbrook \& Daniel R. Fischel, The Proper Role of a Target's Management in Responding to a Tender Offer, 94 HARV. L. REV. 1161 (1981).

14. See PLM Int'l, Inc., SEC No-Action Letter, 1997 SEC No-Act. LEXIS 575 (Apr. 28, 1997).

15. See Union Carbide Corp., SEC No-Action Letter, 1999 SEC No-Act. LEXIS 145 (Feb. 5, 1999).

16. 975 P.2d 907 (Okla. 1999).

17. 968 F. Supp. 1578 (N.D. Ga. 1997).

18. See infra Part V. 
and will continue to stand unless and until the SEC changes its mind.

\section{B. Shareholder Nomination Bylaws}

Shareholders elect directors. However, in the vast majority of instances it is the current board that nominates the directors and includes its nominees in the corporation's proxy materials. It is too expensive for shareholders to circulate their own proxy materials, unless they are trying to obtain a controlling amount of shares, in which case the potential profits from achieving control may be large enough to justify waging a proxy contest if it will help gain control. Boards will generally (indeed, almost uniformly) not include shareholder nominees that they do not want in the corporation's proxy materials unless the SEC were to force them to do so.

One potential way around this is to enact a bylaw that requires the board to include shareholder nominees in the corporation's proxy materials if specified conditions are met. Such bylaws may or may not be valid under state law. However, in order to test that law, shareholders must first be able to pass such proxy access bylaws, and in order to be able to effectively pass such bylaws they must be able to get the bylaw proposal included in the company's proxy materials. Here again, the SEC has not helped shareholders, and has generally allowed corporations to exclude proxy access bylaws, with a few exceptions. ${ }^{19}$

A few years ago, the American Federation of State, County and Municipal Employees Pension Plan tried again with a series of proxy access bylaws at various companies. The SEC allowed the companies to exclude the proposals, ${ }^{20}$ but it announced that it was reconsidering proxy access for shareholder nominees. ${ }^{21}$ Several months later the SEC staff produced a report that examined various options for reform of the nomination process. ${ }^{22}$ One possible reform was to allow proxy access bylaws. ${ }^{23}$

The most controversial proposal would create a requirement to include shareholder nominees in corporate proxy materials under specified circumstances. ${ }^{24}$ The SEC followed up on this suggestion with proposed Rule $14 \mathrm{a}-11 .^{25}$ The rule would require companies to include certain shareholder nominees if one of two triggers applied. The first trigger is that at least $35 \%$ of

19. See infra notes 301-02 and accompanying text.

20. See Staff Report: Review of the Proxy Process Regarding the Nomination and Election of Directors, July 15, 2003, p. 1 [hereinafter Staff Report].

21. See Commission to Review Current Proxy Rules and Regulations to Improve Corporate Democracy, Press Release No. 2003-46 (Apr. 14, 2003).

22. See Staff Report, supra note 20.

23. See Alternative E, Staff Report, supra note 20, at 24-26.

24. See Alternative A, Staff Report, supra note 20, at 6-14.

25. See Release No. 34-48626, Proposed Rule: Security Holder Director Nominations, Oct. 14, 2003. 
shareholders withhold support for a board nominee. ${ }^{26}$ The second trigger is that a majority of shareholders vote to be governed by the $14 \mathrm{a}-11$ regime. ${ }^{27}$ Only shareholders who collectively have held at least $5 \%$ of the outstanding shares for at least two years could nominate shareholders using the rule. ${ }^{28}$ Shareholders could only nominate between one and three directors, depending on how many positions are up for election, and in all events less than a majority of the positions up for a vote. ${ }^{29}$ The proposed rule has been controversial, generating thousands of comment letters. ${ }^{30}$ As of this writing, the rule has not yet been adopted and it appears to be dead.

In the meantime, the SEC's staff has wobbled on the question of whether companies must include shareholder proxy access bylaw proposals. In December 2004 the staff initially denied a no-action request by Disney, which wanted to exclude a proxy access bylaw submitted by AFSCME, the New York State Common Retirement Fund, CalPERS, and the Illinois State Board of Investment. ${ }^{31}$ The proposal would subject Disney to the proposed Rule 14a-11 regime. A few weeks later the staff reversed itself, allowing Disney to exclude the proposal and thus reverting to its traditional position. ${ }^{32}$ The union plans to appeal the staff's decision to the Commission. ${ }^{33}$

This brief account of the background for shareholder bylaws suggests that both state law and SEC rules are important to the practical possibilities of bylaws for empowering shareholders, and we shall consider both below. It also suggests that shareholder bylaws are both controversial and potentially effective at shifting the balance of power between boards and shareholders, and raise interesting policy questions as well.

\section{LEGAL ANALYSIS OF BYLAWS}

This section analyzes existing Delaware law to determine what sorts of provisions bylaws can validly contain. The analysis both provides a general framework for assessing the validity of bylaw provisions, and applies that framework to shareholder proxy access and poison pill bylaws. It focuses on Delaware as the leading corporate law jurisdiction, although a similar question arises in other states.

Bill Eskridge and Phil Frickey have suggested a general framework for

26. See proposed Rule 14a-11(a)(2)(i).

27. See proposed Rule 14a-11(a)(2)(ii).

28. See proposed Rule 14a-11(b).

29. See proposed Rule 14a-11(d).

30. These letters are available at http://www.sec.gov/rules/proposed/s71903.shtml.

31. See The Walt Disney Co., SEC No-Action Letter, 2004 SEC No-Act. LEXIS 863 (December 8 , 2004).

32. See Carrie Johnson, SEC Staff Reverses on Disney Proxy; Ballot Won't Include Nomination Initiative, WASH. POST, Dec. 30, 2004, at El.

33. See id. 
understanding statutory interpretation as practical reasoning. ${ }^{34}$ Their approach recognizes several major sources of authority. They suggest a funnel as a heuristic device for understanding the relationship between these sources. At the bottom of the funnel is the narrowest and most authoritative source: the statutory text itself. In the middle of the funnel are such factors as legislative history, administrative interpretations, and judicial interpretations-less authoritative and more wide-ranging than statutory text. At the top of the funnel are policy considerations, the least authoritative but most wide-ranging source for interpreting statutes. These three levels of analysis link to each other: the policy analysis of Part IV ties to broad themes that emerge from the case law, and that case law is anchored in the statutory text. In this section I consider the lowest and middle levels of the funnel. The first sub-section focuses on statutory text. The second sub-section considers the legislative history of the Delaware statutes and relevant judicial decisions that affect the analysis. Part IV engages in a policy analysis, the top of the funnel.

\section{A. Text}

We start our analysis with two conflicting statutory provisions in Delaware. $^{35}$ Delaware section 141 (a) is the statutory source for a strong presumption in favor of board discretionary control over the business affairs of a corporation. It provides:

The business and affairs of every corporation organized under this chapter shall be managed by or under the direction of a board of directors, except as may be otherwise provided in this chapter or in its certificate of incorporation. If any such provision is made in the certificate of incorporation, the powers and duties conferred or imposed upon the board of directors by this chapter shall be exercised or performed to such extent and by such person or persons as shall be provided in the certificate of incorporation. ${ }^{36}$

The competing provision is section 109(b), which gives a broad sweep to what bylaws may cover:

The bylaws may contain any provision, not inconsistent with law or with the certificate of incorporation, relating to the business of the corporation, the conduct of its affairs, and its rights or power or the rights or powers of its stockholders, directors, officers or employees.

As noted by Jeffrey Gordon, there is a frustrating circularity here, what he

34. See William N. Eskridge, Jr. \& Philip P. Frickey, Statutory Interpretation as Practical Reasoning, 42 STAN. L. REV. 321 (1990).

35. Similar conflicting provisions exist in most if not all other states. See, e.g., MOD. BUS. ACT $\S \S$ 10.20(a), 8.01(b) (1984).

36. DEL. CODE ANN. tit. $8, \S 141$ (a) (2005) (emphasis added).

37. Id. $\S 109$ (b) (emphasis added). 
calls a "recursive loop." 38 One can read the phrase "except as may be otherwise provided in this chapter" in section 141(a) as referring, among other things, to section 109(b), so that section 109(b) trumps section 141(a). Alternatively, one can read the phrase "not inconsistent with law" in section 109(b) as referring, among other things, to section 141(a), so that section 141(a) trumps section 109(b). ${ }^{39}$

This gives rise to three basic possible readings. First, section 109(b) does not on its own validate any sort of bylaw provision, because section 141(a) always trumps it. Second, section 141(a) does not provide any sort of limitation whatsoever on the provisions that section 109(b) allows, because section 109(b) always trumps 141(a). Third, one can split the difference so that section 109(b) does allow for some limitations on matters that otherwise would be subject to board authority, but section 141(a) limits how far such bylaw provisions can go. The question then arises as to how to split the difference.

Does the statutory text give us any sorts of clues as to which of these three possible readings makes most sense of the two provisions? We are guided by the general principle that wherever possible, we should read different statutes together harmoniously, such that effect is given to all provisions. This is the general principle of textualist interpretation that the Delaware courts have specifically endorsed. ${ }^{40}$ Also relevant is the Delaware doctrine of independent legal significance. ${ }^{41}$ Under this doctrine, "action taken pursuant to the authority of the various sections of [the Delaware General Corporation Law] constitute acts of independent legal significance and their validity is not dependent on other sections of the Act., ${ }^{, 42}$ Moreover, we shall not consider only sections 141(a) and 109(b). Rather, we shall bring in the broader statutory context and consider a number of other statutes that bear on bylaws and board power.

Our basic principle, that sections 141(a) and 109(b) should both be given

38. Jeffrey N. Gordon, "Just Say Never?" Poison Pills, Deadhand Pills, and Shareholder-Adopted Bylaws: An Essay for Warren Buffett, 19 CARDOzo L. REV. 511 , 546 (1997).

39. Note that the $\S 109$ (b) exception refers to "law" generally, not the corporation law specifically, unlike $\S 141$ (a)'s exception, which refers to "except as may be otherwise provided in this chapter," i.e., in the corporation law. Thus, one could argue that the $\$ 109$ (b) exception really only refers to other sorts of legal limitations-e.g., that the bylaws may not discriminate on the basis of race, or may not violate the antitrust laws. This weakly suggests that $\S 109(\mathrm{~b})$ trumps $\S 141(\mathrm{a})$. However, although "law" does include more than the corporation law, it would seem to include the corporation law as well.

40. See Henley Group, Inc. v. Santa Fe S. Pac. Corp., No. CIV. A. 9569, 1988 WL 23945, at *16 (Del. Ch. Apr. 12, 1998) ("[T]he relevant principle of statutory construction is that a statute must be interpreted to give full effect to the pertinent statutory language and to produce the most consistent and harmonious result. A court should not normally use rules of construction to amend or override one statutory provision in favor of another, and statutes on the same subject must be construed together so that effect is given to every provision. The Court will choose between statutory provisions only if there is an irreconcilable conflict between the two statutes, in which case the later enacted statute supercedes the earlier one.").

41. See Hariton v. Arco Elecs., Inc., 188 A.2d 123 (Del. 1963); Fed. United Corp. v. Havender, 11 A.2d 331 (Del. 1940).

42. Langfelder v. Universal Lab., 68 F. Supp. 209, 211 (D. Del. 1946). 
the fullest effect possible, already provides a strong argument in favor of the third reading. The first reading, that section 109(b) can never on its own validate any bylaw provision, in effect makes all of section 109(b) null. We should read section 109(b) as having some sort of effect: it should make some bylaw provisions valid that would in its absence not be valid. The most impressive textual analysis of this issue to date, that of Lawrence Hamermesh, comes at least very close to falling afoul of this objection. ${ }^{43}$

Similarly, the second reading, that section 141(a) puts no limits on section 109(b), seems to make one part of section 141(a) superfluous. This second reading hinges on understanding the "except as may be otherwise provided in this chapter" language of section 141 (a) as referring to section 109(b), among other statutory provisions. However, note that this exception language more fully reads "except as may be otherwise provided in this chapter or in its certificate of incorporation." The difficulty arises when we add in consideration of section 102(b)(1), which allows the certificate to contain provisions concerning management of the business and affairs of the corporation. ${ }^{44}$ Section $102(b)(1)$ is similar in scope to section 109(b). If we are to read section 109 (b) broadly to allow bylaws to limit board authority, then section 102(b)(1) would have the same effect. However, since section 102 is in the same chapter as section 109 and section 141, the "except as may be otherwise provided in this chapter" phrase would then point to $102(\mathrm{~b})(1)$ as well as 109 (b). If that is so, though, then why would the exception need to include "or in its certificate of incorporation"? The certificate language in section 141(a)'s exception clause thus becomes superfluous on the second, broad reading of section 109 (b). ${ }^{45}$

An expressio unius argument reinforces this last point. Section 141(a)'s exception clause refers to provisions in the certificate but not in the bylaws. If

43. Hamermesh says "it is preferable to read section 141(a) as an absolute preclusion against bylaw limits on director management authority, in the absence of explicit statutory authority for such limits outside of section 109(b)." Hamermesh, supra note 4, at 444. At other points, Hamermesh says "the most reasonable reading of these statutes precludes reliance on section $109(\mathrm{~b})$ as an independent source of authority for a by-law that directly limits the managerial power of the board of directors." Id. at 430 (emphasis added). Similarly, he says "stockholders lack the general authority to adopt by-laws that directly limit the managerial power of directors." Id. at 479 (emphasis added). The language I have emphasized in the last two quotes suggests that Hamermesh may think that $\S 109$ (b) authorizes indirect limits on board authority, which would give some effect to $\S 109(\mathrm{~b})$, although Hamermesh does not elaborate on the direct/indirect distinction. I shall discuss this a bit more below.

44. Section $102(b)(1)$ reads:

[T] he certificate of incorporation may also contain ... [a]ny provision for the management of the business and for the conduct of the affairs of the corporation, and any provision creating, defining, limiting and regulating the powers of the corporation, the directors, and the stockholders, or any class of the stockholders, or the members of a nonstock corporation; if such provisions are not contrary to the laws of this State. Any provision which is required or permitted by any section of this chapter to be stated in the bylaws may instead be stated in the certificate of incorporation.

$\S 102(b)(1)(2005)$.

45. See Hamermesh, supra note 4, at 431-32. 
the bylaws can indeed limit section 141(a), this would have been a natural place to mention the bylaws, but the statute does not do so. Expressio unius is a commonly-used but rather controversial textual argument. It is not always safe to assume that legislators will have seen that a certain provision could have been inserted and deliberately chose not to. Many absences of this sort are inadvertent. However, in this case the argument is strengthened by the fact that in many other related parts of the Delaware statutes the language refers to the certificate and bylaws together. In section 141 alone this occurs at least seven times. $^{46}$

Both the first and the second readings run afoul of some strong textualist objections. This provides at least a negative argument for the third, split-thedifference reading. The split-the-difference reading does give effect to the "except as may be otherwise provided ... in its certificate of incorporation" language of section 141(a). The split the difference reading only allows some bylaw provisions under section 109(b); section 141(a) forbids other bylaws. Absent the reference to the certificate in section 141(a), the same might be true for certificate provisions limiting board authority. The inclusion of the certificate exception, though, means that the certificate may limit board authority in any way, regardless of the usual grant of authority to the board in section 141(a). ${ }^{47}$ Thus, certificate limitations can go further than bylaw limitations.

Is there any more positive support for that reading? That depends in part on how one proposes to split the difference. The literature contains several possible distinctions for what bylaws can and cannot do under section 109(b), most of them set out in an article by John Coffee. ${ }^{48}$ The four distinctions Coffee suggests are as follows:

Ordinary versus fundamental matters. Bylaws may be more likely to be valid if they concern fundamental rather than ordinary matters. This distinction tracks how the SEC has understood state law in its handling of shareholder proposals. Lawrence Hamermesh objects that fundamental matters are precisely the area where a board's role is most important, and that in practice much of a board's work is focused on fundamental matters. ${ }^{49}$ This proposed distinction would not divest managers of default authority over fundamental matters; it would simply allow bylaws to limit that default board power. The ordinary/fundamental distinction gets some backup from statutorily required shareholder voting: besides electing directors, shareholders have the right to

46. See Del. CODE ANN. tit. 8, §§ 141(b), 141(c), 141(d), 141(f), 141(g), 141(h), 141(i) (2005).

47. Of course, there are some legal limits on what the certificate may do, just not limits derived from $\S 141(a)$.

48. See Coffee, supra note 4.

49. See Hamermesh, supra note 4, at 433-35. 
vote on mergers, ${ }^{50}$ sales of substantially all corporate assets, ${ }^{51}$ dissolutions, ${ }^{52}$ and certificate amendments. ${ }^{53}$ These are all fundamental matters, thus suggesting that the Delaware statutes tend to give shareholders voting power over fundamental matters, but not otherwise. ${ }^{54}$

Affirmative orders versus negative constraints. Bylaws might be valid if they constrain the board, but not if they affirmatively order it to take specific actions. Coffee seems to have derived this distinction from case law rather than statutory language. ${ }^{55}$ Section 141(a) speaks of corporate business being "managed by or under the direction of" the board. The word "manage" may connote affirmatively taking action. Perhaps "relating to" connotes negative constraint on action. However, I do not see why the phrase "relating to" should refer only to bylaws that constrain board action-the words "relating to" do not seem to suggest that distinction.

Procedure versus substance. Bylaws usually seem to focus on procedural rules rather than substantive matters. ${ }^{56}$ The language of sections 141 (a) and 109(b) does not particularly suggest this distinction, although this might be another way of helping to distinguish "manage" and "relating to." The distinction does, however, emerge as a possible way of understanding the list of specific bylaw provisions that other parts of the corporate law allow, so I shall reserve discussion of this distinction until we come to that list.

Corporate governance versus business decisions. Coffee terms the "safest and soundest distinction" that between corporate governance, a valid subject for bylaws, and business decisions, which are reserved to the board. ${ }^{57}$ Corporate governance bylaws "affect the allocation of power between shareholders and directors prospectively (particularly with regard to a broad and generically defined class of cases.) ${ }^{\text {"58 }}$ This may help make sense of the "managed by" versus "relating to" language. Section 109(b) also speaks of provisions relating to the "rights or powers" of stockholders, directors, officers or employees. The phrase "rights or powers" seems to point to structural, governance matters as opposed to business decisions. 59

Hamermesh suggests a fifth possible distinction for distinguishing valid

50. See Del. Code ANN. tit. $8, \S 251$ (2005).

51. See id. $\$ 271$.

52. See id. § 275.

53. See id. $\$ 242$.

54. See Coffee, supra note 4, at 613-14.

55. See id. at 614 .

56. See id.

57. See id. at 614-15.

58. Id. at 614 .

59. Even Hamermesh agrees that bylaws directed at specific business decisions are "less defensible," although he believes that even broad corporate governance bylaws are hard to defend. However, his objections to this distinction are really aimed not at the distinction itself, but rather at whether poison pill bylaws fall on the corporate governance side of the distinction. See Hamermesh, supra note 4 , at $437-42$. 
from invalid bylaw provisions:

Direct versus indirect. Bylaw provisions that indirectly limit board managerial authority may be allowable. ${ }^{60}$ The "relating to" language of section 109(b) may provide some support for this distinction. However, it is far from clear how one would make the direct/indirect distinction in practice.

Thus, the statutory language that we have considered so far seems most consistent with a split-the-difference interpretation that gives effect to both sections 109(b) and 141(a) by distinguishing bylaws that section 109(b) allows from bylaws that section 141(a) forbids. The language supports several ways of making this distinction, with the corporate governance/business decision distinction receiving the most support.

Many other provisions of the Delaware General Corporation Law touch on the allocation of power between boards and shareholders and how the certificate and bylaws may affect that allocation. We should consider those provisions and see which approach they tend to support.

The Delaware General Corporation Law contains several other provisions that allow for broad constraints on the board's management authority. Of most interest to us here is section 350 , which allows for shareholder agreements that may restrict the board's authority in close corporations. ${ }^{61}$ Section 350 reads as follows:

A written agreement among the stockholders of a close corporation holding a majority of the outstanding stock entitled to vote, whether solely among themselves or with a party not a stockholder, is not invalid, as between the parties to the agreement, on the ground that it so relates to the conduct of the business and affairs of the corporation as to restrict or interfere with the discretion or power of the board of directors. The effect of any such agreement shall be to relieve the directors and impose upon the stockholders who are parties to the agreement the liability for managerial acts or omissions which is imposed on directors to the extent and so long as the discretion or powers of the board in its management of corporate affairs is controlled by such agreement. ${ }^{62}$

Section 350 clearly allows shareholder agreements to limit board authority in close corporations, and is thus one of the sections that the "except as may be otherwise provided in this chapter" proviso of section 141(a) refers to. Section 350 may show how a statute can be specifically drafted to provide for broad permission to limit management authority under section 141(a). The fact that section 350 is limited to close corporations may suggest that shareholders alone should not be able to limit board authority outside the close corporation

60. See supra note 43 for relevant passages.

61. Close corporations, as defined in Delaware, must have no more than thirty shareholders, have transfer restrictions on their shares, and have made no public offering of their shares. See DEL. CODE ANN. tit. 8, § $342(2005)$.

62. Id. $\S 350$. 
context, as a broad interpretation of section 109(b) would allow. Both sections 109(b) and 350 refer to the business and affairs of the corporation and the powers of the board. Section 350 does more specifically refer to restricting or interfering with the powers of the board, whereas section 109(b) refers more generally to anything relating to the business or affairs or powers. However, given the breadth of powers that section 141(a) grants to the board, it is hard to see how any bylaw provision that relates to board power authorized under section 109(b) could do anything other than restrict board power.

The other provisions that allow for shifting of power from the board are sections 226, which allows the Court of Chancery to appoint a custodian or receiver where the directors and shareholders are badly divided, ${ }^{63}$ and section 351 , which provides that the certificate of a close corporation may provide that shareholders shall manage the business of the corporation. ${ }^{64}$ The fact that section 351 does not specify that bylaws may provide for shareholder management is some evidence against a broad reading of section 109(b). Many provisions contain more specific rules allocating power between boards and shareholders.

A number of provisions allow for bylaws to set the rules:

Bylaws may set the number of directors, require that directors must be stockholders, set qualifications for directors, and set a quorum for board action. $^{65}$

Bylaws may set board committee quora and specify the powers of committees. ${ }^{66}$

Initial bylaws or bylaws adopted by shareholders may create staggered boards. ${ }^{67}$ The fact that board-adopted bylaws cannot create staggered boards is of note.

Bylaws may restrict the ability of the board to act by written consent. ${ }^{68}$

Bylaws may restrict the ability of the board to meet outside of Delaware. ${ }^{69}$

Bylaws may restrict the ability of the board to set director compensation. ${ }^{70}$

Bylaws may restrict the ability of the board to meet by phone or similar communications. $^{71}$

Bylaws may specify officer titles and duties. ${ }^{72}$

Bylaws may specify the terms and manner of choosing officers. ${ }^{73}$

63. See id. $\S 226$.

64. See id. $\$ 351$.

65. See id. § 141(b).

66. See id. $\$ 141(\mathrm{c})$.

67. See id. $\$ 141(\mathrm{~d})$.

68. See id. § 141(f).

69. See id. $\$ 141(\mathrm{~g})$.

70. See id. §141(h).

71. See id. $\$ 141(\mathrm{i})$.

72. See id. §142(a). 
Bylaws may specify the manner for filling officer vacancies. ${ }^{74}$

Bylaws may create indemnification rights. ${ }^{75}$

Corporations may in their bylaws opt out of section 203, the Delaware business combination statute. $^{76}$

Bylaws may set the location for shareholder meetings. ${ }^{77}$

Bylaws may set the date and time for shareholder meetings. ${ }^{78}$

Bylaws may specify persons who can call special stockholder meetings. ${ }^{79}$

Bylaws may set the quorum for stockholder meetings. ${ }^{80}$

Bylaws may require notice of adjourned stockholder meetings. ${ }^{81}$

Bylaws may provide for how to fill board vacancies. ${ }^{82}$

Some provisions, however, mention the certificate but not the bylaws as a method for setting certain rules. These include:

The certificate may give a class of stockholders the right to elect one or more directors. ${ }^{83}$

The certificate in a corporation not authorized to issue capital stock may provide that less than one-third of the members of the governing body may constitute a quorum. ${ }^{84}$

The certificate may allow removal of directors without cause in corporations with staggered boards. ${ }^{85}$

The certificate may provide for rights and limitations on classes of stock. ${ }^{86}$

The certificate may provide for dividend rights for classes of stock. ${ }^{87}$

The certificate may provide for rights upon dissolution for classes of stock. $^{88}$

The certificate may provide for the convertibility of classes of stock. ${ }^{89}$

The certificate may regulate the creation and issuance of rights and options respecting stock. ${ }^{90}$

73. See id. § 142(b).

74. See id. $\S 142(\mathrm{e})$.

75. See id. § 145(f).

76. See id. § 203(b).

77. See id. § 211(a).

78. See id. $\S 211$ (b).

79. See id. § 211(d).

80. See id. $\S \S 215(\mathrm{c}), 216$.

81. See id. § 222(c).

82. See id. § 223.

83. See id. § 141 (d).

84. See id. \&141(j).

85. See id. § 141(k)(1).

86. See id. §151(a).

87. See id. §151(c).

88. See id. § 151(d).

89. See id. § 151(e).

90. See id. $\S 157$. We shall see that this provision along with the $\S 151$ provisions is of particular 
The certificate may limit the ability of shareholders to act by written consent. $^{91}$

The certificate may provide that elections of directors are not by written ballot. $^{92}$

The certificate may vary the one share/one vote rule..$^{93}$

The certificate may provide for cumulative voting. ${ }^{94}$

The certificate may give bondholders the power to vote "in respect to the corporate affairs and management of the corporation." 95

The certificate may limit the ability of stockholders to act by written consent. $^{96}$

Does any pattern emerge from this list of statutory provisions? Consider first the specific provisions that may be included in bylaws. Most of these provisions focus on rules structuring board decision making, ${ }^{97}$ the duties and appointment of officers, ${ }^{98}$ and the procedures for shareholder meetings. ${ }^{99}$ These provisions seem particularly consistent with the procedure/substance and corporate governance/business decision distinctions discussed above. Certainly the board decision making rules of section 141 and the shareholder meeting rules can be plausibly described as procedural, as can many of the officerrelated provisions of section 142. This distinction does not explain all of the specific bylaw provisions, though. Indemnification, ${ }^{100}$ the duties of officers, ${ }^{101}$ and opting out of the section 203 business combination rule, ${ }^{102}$ for instance, do not obviously fall on the procedural side of the procedure/substance decision. All of the listed provisions that bylaws may include do seem to fall on the corporate governance side of the corporate governance/business decision distinction, but so do many of the listed provisions that can be included in the certificate but not the bylaws.

Is there any logic to when the Delaware law removes a matter from the power of bylaws to alter? Some of the provisions would have the potential to alter the balance of power between the board and shareholders, and in particular to provide enhanced power to the board. Removing such provisions from the reach of bylaws may help to protect against overreaching board-

interest with respect to poison pill bylaws.

91. See id. §211(b).

92. See id. $\$ 211(\mathrm{e})$.

93. See id. $\S \S 212(\mathrm{a}), 215(\mathrm{~b})$.

94. See id. $\$ 214$.

95. See id. $\S 221$.

96. See id. $\$ 228$.

97. See generally id. \$ 141 .

98. See generally id. $\S 142$.

99. See generally id. $\S \S 211,215,216,222$.

100. See id. $\S 145(\mathrm{f})$.

101. See id. § 142(a).

102. See id. $\S 203$. 
passed bylaws. I would put the provisions on class directors, ${ }^{103}$ removal of directors, ${ }^{104}$ action by written consent, ${ }^{105}$ and one share/one vote ${ }^{106}$ in this category. Note that shareholder-passed bylaws do not pose a similar threat. In the case of staggered boards, the statute actually distinguishes between boardpassed and shareholder-passed bylaws, allowing the latter but not the former to create a staggered board. ${ }^{107}$ However, the fact that the law makes that distinction in that section but not the others does weaken the point for those other sections.

A second category includes the provisions concerning the rights of different classes of shares. ${ }^{108}$ It is more of a puzzle why this area is taken out of the bylaw power. Perhaps the statutory drafters conceived of issuing stock as an ordinary business decision or substantive matter. Larger corporations issue shares quite regularly. Issuing shares is a question of corporate finance, and in some cases also of employee compensation. These are the kinds of business decisions that fall into the competence of the board. However, defining share rights can also be an important matter of corporate governance, as poison pills make very clear. Creation of special classes of shares or rights to receive shares can be an important form of antitakeover defense. Perhaps here too there was a fear of the misuse of board-passed bylaws. Or perhaps this use of the power to issue different types of shares was not as clear and significant at the time these statutes were created.

A final category of the provisions that cannot be included in bylaws is miscellaneous. Here I would include cumulative voting ${ }^{109}$ and bondholder voting. ${ }^{110} \mathrm{I}$ have no good theory for why these provisions cannot be in the bylaws. That is not a catastrophic failing, I hope. I am aware of no theory that perfectly explains the full pattern of what can and cannot be included in the bylaws. Given the vagaries of legislative drafting of many different provisions at many different points in time, it is probably asking too much of any explanation that it fully account for all parts of the law.

Overall, our examination of statutory textual provisions suggests the following approach to what bylaws may do. Courts should first compare a bylaw with the statutory provisions that either allow for or exclude bylaws. If the bylaw falls within one or the other type of specific provision, that provision prevails. ${ }^{11}$ If the bylaw does not fall squarely within a specific provision, one

103. See id. $\S 141(\mathrm{~d})$.
104. See id. $\S 141(\mathrm{k})(1)$.
105. See id. $\S \S 211(\mathrm{~b}), 228$.
106. See id. $\S 212(\mathrm{a})$.
107. See id. $\S 141(\mathrm{~d})$.
108. See id. $\S \S 151,157$.
109. See id. $\S 214$.
110. See id. $\S 221$.
111. A common interpretive canon provides that specific statutes should prevail over general 
must move on to general distinctions between valid and invalid bylaws. If in applying the general distinctions the bylaw seems closely related to one type of specific statutory provision, those specific provisions and how they treat bylaws should help guide how one applies the general distinctions. The best general distinctions between valid and invalid bylaws are those that Coffee has suggested, with the corporate governance/business decision distinction as the best, and the procedure/substance and ordinary/fundamental distinctions also providing some help. No one of these distinctions fully explains the statutory patterns on its own; courts probably will and should wield several of the distinctions in attempting to apply the statutes to specific bylaws. Bylaws that fall on the corporate governance, procedure, and fundamental side of the distinctions are most likely to be upheld; bylaws that fall on the business, substance, and ordinary side are most likely to be struck down; and bylaws that follow a mixed pattern present an intermediate case. ${ }^{112}$

To see how this approach works in practice, let us apply it to shareholder proxy access bylaws and to poison pill bylaws. Shareholder proxy access bylaws present the easier case. Shareholder proxy access does not fall squarely within any specific statutory provision. However, we have seen that bylaws may set many procedural rules for shareholder meetings, a topic closely related to proxy access. ${ }^{113}$ Moreover, corporate law vests shareholders, and in general shareholders only, with the power to elect directors. ${ }^{114}$ The fundamental power to elect would seem to carry with it the power to nominate, and in most public corporations today the power to nominate is effective only if shareholders can use the corporate proxy. ${ }^{115}$ Indeed, Mel Eisenberg has used this argument, combined with the ban on using corporate facilities for the personal benefit of directors, to argue that even in the absence of a bylaw or certificate provision on point shareholders have the right to use the corporate proxy to nominate

statutes.

112. I note a different possible approach, suggested in comments by Larry Solum. One could distinguish between shareholder-passed and board-passed bylaws, arguing that board-passed bylaws do not infringe upon the board's section 141(a) prerogatives while shareholder-passed bylaws do. That point makes a lot of sense, but there are several difficulties. First, in one place where Delaware law distinguishes between shareholder and board-passed bylaws, it allows the former and not the latter, the opposite of the suggestion being considered here. See DEL. CODE ANN. tit. 8, § 141(d) (2005). Second, the Delaware Supreme Court's Quickturn decision, discussed below, invalidating no-hand poison pills, treats board limits on board power as forbidden under section 141(a). See Quickturn Design Sys. v. Shapiro, 721 A.2d 1281 (Del. 1998). Third, as a policy matter this suggested approach negates the use of shareholder bylaws to limit board misbehavior, the key idea that underlies this paper, discussed further in Part IV.

113. For instance, bylaws may provide for the time and location of shareholder meetings, may allow a set percentage of shareholders to call for a special meeting, and may set the quorum for shareholder meetings.

114. See DEL. CODE ANN. tit. 8, $\S 212$ (2005). Unusually, in Delaware the certificate may give bondholders the right to vote. See id. $\$ 221$. Certificates rarely do so, however.

115. See Melvin Aron Eisenberg, Access to the Corporate Proxy Machinery, 83 HARV. L, REV. $1489,1505(1970)$. 
directors. ${ }^{116}$ I do not need to go that far; I merely argue that bylaws may provide for shareholder access to the corporate proxy.

Applying the general distinctions as to what bylaws are valid, proxy access bylaws cover a general matter of corporate governance, not specific business decisions. They also deal with procedure rather than substance. Thus, on the two most important criteria, proxy access bylaws appear valid. It is less clear whether they are a fundamental or ordinary business matter, although given the central role of shareholder voting in the prevailing justifications of our system of corporate governance, and given the practical significance of proxy access for meaningful shareholder voting, it is at least quite arguable that this is a fundamental matter. The approach suggested by this section's reading of the statutes suggests that shareholder access bylaws are valid under Delaware law.

Note that while this interpretation of the statutes gives shareholder activists a new tool against recalcitrant management, it also presents a threat to them as well. If shareholder bylaws can regulate in this area, then board bylaws can as well. A board bylaw might regulate the procedure by which shareholders may propose and approve bylaws. Two possible kinds of board bylaws regulating the bylaw process come to mind. The first of these is advance notice bylaws, which require notice a set period of time before a meeting if shareholders intend to present a proposal at that meeting. This would appear to be the sort of procedural regulation of shareholder voting that is closely related to explicit bylaw powers, it qualifies as procedural rather than substantive, and it covers a matter of general corporate governance. Indeed, such advance notice bylaws are already common. ${ }^{117}$ There is probably an outer bound to such bylaws. A notice bylaw that set the notice period too far in advance (say 100 years, to make the point at the absurd limit) would effectively divest shareholders of their power to adopt, amend or repeal bylaws, in violation of section 109(a). ${ }^{118}$ There are also fiduciary duty limits on the ability of boards to enact such a bylaw -if a Delaware court sees such a bylaw as being enacted for the primary purpose of disenfranchising shareholders, it will strike it down. ${ }^{119}$

The second type of possible board bylaw would set high barriers for when shareholder bylaw proposals could be included in the corporate proxy materials. The main legal challenge to such a bylaw would come not under state law, but rather under federal securities law, and in particular under Rule 14a-8. Indeed, bylaws which set higher barriers to inclusion of shareholder bylaws than that rule allows may be invalid for corporations subject to the rule.

116. See id. at 1505-08.

117. See Hamermesh, supra note 4, Appendix A.

118. See DeL. CODE ANN. tit. 8, § 109(a) (2005) ("The fact that such power has been so conferred upon the directors or governing body, as the case may be, shall not divest the stockholders or members of the power, nor limit their power to adopt, amend or repeal bylaws.").

119. See Chesapeake Corp. v. Shore, 771 A.2d 293 (Del. Ch. 2000). 
Poison pill bylaws present a tougher case than shareholder proxy access bylaws. First, poison pill bylaws may be actually covered by two specific statutory provisions, sections 157 and 151. The Delaware Supreme Court looked to these two sections in concluding that boards have the right to create poison pills, although it also pointed to section 141(a) as supplementary authority. ${ }^{120}$ Section 157 provides that "[s]ubject to any provisions in the certificate of incorporation, every corporation may create and issue ... rights or options entitling the holders thereof to purchase from the corporation any shares of its capital stock of any class or classes." 121 The fact that section 157 allows the certificate but not the bylaws to regulate the creation and issuance of stock rights is probably the single most powerful argument against poison pill bylaws. Against this, one can argue that section 157 does not delegate exclusive authority to the board, saying the corporation may create and issue stock rights. ${ }^{122}$ But even if one accepts that point, the section's language may require shareholders to act, or to acquire the power to act, through the certificate rather than through a bylaw. One can also argue that the quoted language allows only the certificate to limit the basic power to create and issue poison pills, but that the bylaws may specify procedures that the board must follow, including requiring shareholder approval, in order to create, amend, or repeal a particular rights plan.

Section 157 also provides that "[t]he terms upon which, including the time or times which may be limited or unlimited in duration, at or within which, and the price or prices at which any shares may be purchased from the corporation upon the exercise of any such right or option, shall be such as shall be stated in the certificate of incorporation, or in a resolution adopted by the board of directors." ${ }^{\prime 23}$ Note again the absence of a reference to bylaws. A proponent of poison pill bylaws can again reply, though, that such bylaws do not specify the terms of the poison pills; they only specify the procedure by which corporations can decide to exercise their power to create and issue rights plans.

Poison pill plans are also in some tension with the language of section 151. Section 151 allows corporations to create different classes and series of shares, with different powers, rights, and restrictions. These different powers, rights, and restrictions can be set forth in the certificate or in board resolutions where the certificate provides for such resolutions. ${ }^{124}$ Note the absence of reference to the bylaws. Here again, poison pill bylaws do not specify the powers, rights, or restrictions of rights plans, and hence section 151 does not directly govern.

Thus, it is arguable whether section 157 directly prohibits poison pill

120. See Moran v. Household Int'l, Inc., 500 A.2d 1346, 1351-53 (Del. 1985).

121. DEL. CODE ANN. tit. 8, §157 (2005).

122. The court in Fleming makes this point. See Int'l Bhd. of Teamsters Gen. Fund v. Fleming Cos., 975 P.2d 907, 911 (Okla. 1999).

123. Del. CODE ANN. tit. 8, § 157 (2005).

124. See id. $\$ 151$. 
bylaws. If it does, that should resolve the question under current law, without having to consider less specific statutes such as sections 109 and 141. Even if sections 157 and 151 do not directly resolve the legal issue, they are certainly closely-enough related to the topic that they should influence how we apply the general distinctions between valid and invalid bylaws.

Professor Coffee has already applied his distinctions and concluded that bylaws may require that shareholders must approve future pills, and may require a shareholder vote to amend, repeal or waive existing pills. Bylaws may not, however, require the board to redeem an existing pill. ${ }^{125}$ Professor Hamermesh, for instance, has argued that even if phrased in a general, prospective, way, pill bylaws "would necessarily act principally in respect of a specific (present or future) takeover effort and thus would not constitute some general corporate governance rule." ${ }^{, 26}$ A particular shareholder vote, required by a bylaw, as to whether to create, amend, or repeal a pill at a specific point in time does indeed look like a specific business decision. However, giving shareholders the general right to vote on that matter, which is what a pill bylaw does, is a general matter of corporate governance.

Poison pill bylaws, at least of the type that Coffee sees as valid, also appear to be procedural rather than substantive: they specify a procedure, namely shareholder approval, that corporations must follow in order to create, amend, or repeal a pill. The ordinary/fundamental distinction is again a bit harder to apply. In form, pills are simply the issuance of rights to purchase shares, an ordinary business matter, a point Hamermesh emphasizes. ${ }^{127}$ However, their practical effect, at least in combination with a staggered board and a limit on removal without cause, is to make hostile takeovers close to impossible, which is a fundamental matter in corporate governance.

Thus, on the whole at least some poison pill bylaws would seem to fall within the valid sphere that section 109(b) creates. If sections 157 and 151 referred to bylaws as well as the certificate, I would conclude that prospective pill bylaws are valid. However, those two specific sections create a strong argument that poison pills fall within an area that corporations must regulate using the certificate rather than the bylaws. It is not easy to predict how a court should or will resolve this question, although on balance I argue that courts should treat poison bill bylaws as valid. This analysis contrasts with the analysis of shareholder proxy access bylaws, which we have seen are most likely valid under the statutory analysis advocated in this subsection.

125. See Coffee, supra note 4 , at 615 .

126. Hamermesh, supra note 4, at 441.

127. See id. 


\section{B. Legislative History and Judicial Interpretations}

Statutory text is the starting point for a legal analysis of the bylaw power, but it is not the end point. At least where the text contains ambiguities, courts will typically look to legislative history, judicial interpretations of the relevant provisions, and administrative agency interpretations as further guides. These represent moves up within the Eskridge and Frickey funnel. ${ }^{128}$ There is no relevant administrative agency in this area, so that will not help us. There is some, although not a lot, of relevant legislative history, so we will look at that first in this sub-section. We will then turn to consider legal cases. Here there is much material indeed, and Delaware courts are likely to pay a lot of attention to this material. What follows is a relatively brief overview of the leading caselaw that is relevant to the matter of the bylaw power.

Variants of both section 141(a) and section 109(b) have been around in the Delaware statutes for a long time. Section 141(a) began as 21 Del. Laws ch. $273, \S 20$ in the 1899 Delaware corporation law: "The business of every corporation organization under the provisions of this Act shall be managed by a board of not less than three directors, except as hereinafter provided." Note that at this point the statute did not refer to the certificate as a way to opt out of the board's broad authority. The reference to the certificate had been added by 1929, when the statute read: "The business of every corporation organized under the provisions of this Chapter shall be managed by a Board of Directors, except as hereinafter or in its Certificate of Incorporation otherwise provided." 29 The provision remained largely the same through the 1967 rewriting of the Corporation Law, except that "the except as otherwise provided" proviso is slightly reworded. ${ }^{130}$ The current version of section 141(a) came into place in 1974, as the language was amended to refer to the "business and affairs of the corporation" and as it specified that this shall be managed "by or under the direction of a board of directors." 131 For our purposes, the main points of interest in section 141(a) were thus in place by 1929.

The bylaw provision also has old ancestors, although its language has changed somewhat more. In 1874 the Delaware law contained a provision that "All corporations shall . . be capable . . to make by-laws, consistent with the laws of the State, for their own government and the management of their property." ${ }^{132}$ In 1915, the provision read: "Every corporation . . . shall have power: .. . [to] make by-laws not inconsistent with the Constitution or laws of

128. See Eskridge \& Frickey, supra note 34.

129. 36 Del. Laws ch. $135, \S 9$ (1929).

130. In the newly-numbered $\$ 141$ (a), that phrase had taken on its modern wording: "except as may be otherwise provided in this chapter or in its certificate of incorporation." 56 Del. Laws ch. $50, \S 141$ (a) (1967).

131. 59 Del. Laws ch. 437 (1973) (emphasis added).

132. DEL. REV. STAT. ch. $70, \S 1$ (1874). 
the United States or of this State, fixing and altering the number of its directors, for the management of its property, the regulation and government of its affairs and for the certification and transfer of its stock." 133 This provision stayed in place until the current section 109(b) was added in $1967 .{ }^{134}$ Thus, in 1967 the bylaw provision went from giving the power to make rules for the management of property and for the regulation and government of its affairs to the more indirect current language to make rules that relate to the business of the corporation. As noted above, this more indirect language in the bylaw provision helps justify the affirmative versus negative constraint, procedure versus substance, corporate governance versus business decisions, and direct versus indirect distinctions. ${ }^{135}$ The fact that the bylaw statutory provision was at one point changed from more indirect language provides some support for the argument that this distinction matters. ${ }^{136}$

Case law can probably provide more insight than the history of the statutory provisions. There are just two state cases directly on point for poison pill bylaws, and to my knowledge none for proxy access bylaws. One of those is the Oklahoma case mentioned earlier, International Brotherhood of Teamsters General Fund v. Fleming Companies. ${ }^{137}$ The bylaw in Fleming required shareholder approval for a poison pill. The relevant Oklahoma law is very close in language to Delaware law. ${ }^{138}$ The Oklahoma Supreme Court held that the bylaw was valid. However, its discussion did not focus on the tension between the analogs of sections 141(a) and 109(b); indeed, it ignored the section 141(a) analog. Rather, the court focused on the interplay between the analog of section 109(b) and of section $157 .{ }^{139}$ This immediately reduces the persuasive authority of the opinion, as most commentators on this topic have focused on the importance of provisions like section 141(a), and as we shall see, Delaware courts are likely to do so as well. The Fleming case simply does not speak to the broad grant of authority to boards that all American corporation laws contain.

However, Fleming could still be of great interest for our previous statutory analysis, since section 157 proved there to be the biggest obstacle to poison pill bylaws. ${ }^{140}$ However, even on this point the case proves disappointing. The main argument that the Fleming board seems to have made is that the statute provides that "every corporation may create and issue ... rights and

133. DEL. CODE 1916 ch. $65, \S 2(6)$ (1915).

134. See Hamermesh, supra note 4 , at 451 n.181.

135. See supra notes $49-60$ and accompanying text.

136. See Hamermesh, supra note 4 , at 451 n.181.

137. 975 P.2d 907 (Okla. 1999).

138. Compare DEL. CODE ANN. tit. 8, § 109(b) (2005), with OKLA. STAT. tit. 18, $\S 1013$ (b) (1991).

139. See OKLA. STAT. tit. $18, \S 1038$ (1991).

140. See supra notes $120-24$ and accompanying text. 
options," 141 which is identical to Delaware's language. ${ }^{142}$ The board seems to have tried to conflate "corporation" with "board of director," a poor argument which the Oklahoma court easily puts down. However, as we have seen, the real challenge of section 157 to poison pill bylaws is the expressio unius argument that the statute makes creation of rights and options subject to provisions in the certificate, but does not mention provisions in the bylaws. ${ }^{143}$ The court does mention that the Fleming board argued that only the certificate can limit the board's authority to implement a rights plan. ${ }^{144}$ The court agreed that the certificate could limit bylaw power, but noted that the certificate in Fleming contained no limitation on the issuance of rights or options. ${ }^{145}$ Thus the court failed to grasp the force of the expressio unius point, that rules about rights or options may only be made in the charter. Accordingly, Fleming provides incomplete guidance on the statutory scope of bylaw power.

The other state case directly on point, Invacare Corp. v. Healthdyne Technologies, Inc., ${ }^{146}$ interprets Georgia law. The Invacare court held that Georgia law does not allow shareholders to enact a bylaw requiring the board to remove a continuing director provision in a poison pill. However, the language of the Georgia statute differs somewhat from the language in Delaware. The Georgia equivalent to section 157 contains language giving the board the sole authority to determine the terms of rights, options, and warrants. ${ }^{147}$ The court relied heavily on that language. ${ }^{148}$ On the other hand, other parts of the Georgia statute at the time actually favored shareholder poison pill bylaws more than Delaware law. For instance, the Georgia analog to Delaware section 141(a) stated that the board's power to manage the corporation is "subject to any limitation set forth in the articles of incorporation, bylaws approved by the shareholders, or agreements among the shareholders which are otherwise lawful." shareholder-approved bylaw language just cited is that another section of the Georgia code provided that no agreement by all shareholders, whether embodied in the articles of incorporation, bylaws, or any written agreement, is invalid on the grounds that it restricts the board's powers, but that this provision does not apply to corporations listed on a national securities

141. See Int'l Bhd. of Teamsters Gen. Fund v. Fleming Cos., 975 P.2d 907, 911 (Okla. 1999).

142. See Del. Code ANN. tit. $8, \S 157$ (2005).

143. See supra notes $120-24$ and accompanying text.

144. See Fleming, 975 P.2d at 912.

145. See id.

146. 968 F. Supp. 1578 (N.D. Ga. 1997).

147. Id. at 1580 ("Nothing contained in Section 14-2-601 of this Part shall be deemed to limit the board of directors' authority to determine, in its sole discretion, the terms and conditions of the rights, options, or warrants issuable pursuant to this Code section." (quoting GA. CODE ANN. § 14-2-624(c) (1997)).

148. See Id. at 1582.

149. GA. CODE ANN. § 14-2-801(b) (1997). 
exchange. ${ }^{150}$ However, Delaware also has no close analog to that language, although section 350 comes closest. Even in interpreting Georgia law, the use of the shareholder agreement statutory language to limit the rather clear language in the analog to section 141(a) allowing shareholder bylaws to limit board authority is rather dubious. Attempting to apply the court's analysis to Delaware is even more suspect because of the many differences between the statutes. Most of the critical statutory language in Georgia is not present in Delaware. Thus, Invacare provides little help in interpreting Delaware law on poison pill bylaws.

While Delaware itself has no case directly on point, there are a few cases with language that comes pretty close to being on point. Perhaps the closest is Quickturn Design Systems, Inc. v. Shapiro. ${ }^{151}$ Quickturn struck down a "no hand" poison pill under which no board could redeem the pill for six months after taking office if the purpose would be to help an interested person take control. ${ }^{152}$ The Delaware Supreme Court found that this provision restricted the board's power "in an area of fundamental importance to the shareholdersnegotiating a possible sale of the corporation. Therefore, we hold that the Delayed Redemption Provision is invalid under Section 141(a), which confers upon any newly elected board of directors full power to manage and direct the business and affairs of a Delaware corporation." 153 This is already a striking affirmation of the importance of section 141(a) and its broad grant of authority, which we shall see is a common theme in Delaware case law. Even more striking, though, is the Court statement that "Section 141(a) requires that any limitation on the board's authority be set out in the certificate of incorporation." 154 If we could take this sentence literally, it would seem to settle the debate in favor of limited bylaw power.

However, we cannot take the sentence literally. Section 141(a) clearly allows limitation as otherwise provided for in the corporation law, not just in the certificate. Thus, under section 350 shareholder agreements can clearly limit board authority in a close corporation. The Quickturn dictum, taken literally, would deny that point, but to that extent, at least, the dictum is just wrong. The key statutory question for the power of bylaws is whether section 109 (b) is another one of the provisions to which section 141(a) refers. Quickturn does not answer that question, because it does not correctly parse the relevant statutory language. Moreover, Quickturn involves a board limiting future board power in a context where entrenchment is a serious concern. That context differs significantly from our context, where shareholders are trying to

150. See Invacare Corp., 968 F. Supp. at 1582 (citing GA. CODE ANN. § 14-2-731(c)).

151. 721 A.2d 1281 (1998).

152. See id. at 1287 .

153. Id. at $1291-92$ (emphasis in original).

154. Id. at 1291. 
use the bylaws to limit a board's ability to entrench itself. Thus, like Fleming, Quickturn is of limited use, although it is a strong example of the heavy emphasis the Delaware courts put on board authority.

Several Delaware cases speak to the scope of the bylaw power. The oldest and broadest of these is Gow v. Consolidated Coppermines Corp. ${ }^{155}$ Gow held that bylaws could enlarge the size of the board despite a certificate provision to the contrary. The court reasoned that the relevant statutory provision specified that the bylaws set board size, and did not mention the certificate. ${ }^{156}$ That specific result would not be reached today, as the contemporary law is clear that the certificate overrides the bylaws and that the certificate can regulate any matter that the bylaws can. ${ }^{157}$ Of continuing interest, though, is the Chancery Court's description of the general scope of bylaws. The court said "the by-laws are generally regarded as the proper place for the self-imposed rules and regulations deemed expedient for its convenient functioning to be laid down." ${ }^{\text {"158 }}$ The case thus supports both the ordinary/fundamental matters and procedure/substance distinctions. ${ }^{159}$

Two more recent cases on the scope of the bylaw power are Datapoint Corp. v. Plaza Securities Co. ${ }^{160}$ and Allen v. Prime Computer, Inc. ${ }^{161}$ Both cases dealt with bylaws delaying the effectiveness of actions taken by shareholder written consent. In analyzing these bylaws the court focused on whether they were consistent with section 228 , which allows shareholder action by written consent. The court read that provision as not allowing a delay in the effectiveness of action by written consent except for ministerial reasons, which are to confirm that the written consent has been properly attained. This is thus a relatively narrow reading of the bylaw power, even in an area (voting procedure) that is rather close to the core of the traditional power of bylaws. However, the court focused on a specific statutory provision, not on the general provisions of sections 109 and 141. In that sense the cases resemble Gow.

Two other recent cases that tend to give a broad scope to the bylaw power are Frantz Manufacturing Co. v. EAC Industries ${ }^{162}$ and Hollinger International v. Black. ${ }^{163}$ In Frantz the court approved bylaw amendments that required unanimous attendance and approval for any board action, saying "the bylaws of a corporation are presumed to be valid, and the courts will construe the bylaws

155. 165 A. 136 (Del. Ch. 1933).

156. Id. at $139-42$.

157. See DEL. CODE ANN. tit. 8, $\S \S 109(\mathrm{~b}), 102(\mathrm{~b})(1)$ (2005).

158. $165 \mathrm{~A}$. at 140 .

159. See supra notes $49-54,56$ and accompanying text.

160. 496 A.2d 1031 (Del. 1985).

161. 540 A.2d 417 (Del. 1988).

162. 501 A.2d 401 (Del. 1985)

163. 844 A.2d 1022 (Del. Ch. 2004). 
in a manner consistent with the law rather than strike down the bylaws."164 In Hollinger, the court held that a bylaw amendment that eliminated a special committee was valid, although it struck down the amendment as inequitable. In doing so, the court noted "the capacious authority over a board's processes that $\S 109$ and other provisions of $\S 141$ plainly grant." ${ }^{\text {"65 }}$ The court also noted the ongoing scholarly debate over poison pill amendments.

Two other recent cases refer in passing to the debate over shareholder bylaws: Jones Apparel Group, Inc. v. Maxwell Shoe Co. ${ }^{166}$ and General DataComm Industries, Inc. v. State of Wisconsin Investment Board ${ }^{167}$ In Jones Apparel the court uses the debate to point out that the Delaware General Corporation Law is not always "a model of drafting consistency." DataComm, the Chancery Court came close to facing our issue squarely. The case involved a proposed bylaw forbidding the board from repricing options without shareholder approval, thus squarely raising the question of the power of bylaws to limit board authority. However, the bylaw had not been adopted by shareholders, it was merely proposed, and hence the court concluded that the case was not ripe. ${ }^{169}$ Vice Chancellor Strine had this to say on the merits:

It may be that GDC is correct in stating that the Repricing Bylaw is obviously invalid under the teaching of Quickturn. But the question of whether a stockholderapproved bylaw that can potentially be repealed at any time by the GDC board of directors exercising its business judgment ... is clearly invalid under the teaching of a case involving a board-approved contractual rights plan precluding, by contract, a new board majority from redeeming the rights under the plan until six months after election seems to me to be a question worthy of careful
consideration.

The first sentence could suggest that Strine is inclined to find a limited general bylaw power, but the second sentence suggests a possible inclination to distinguish Quickturn and find a broader bylaw power when exercised by shareholders to limit board authority.

What Delaware courts have had to say on the specific topics of shareholder nominations and access to the proxy machinery and of poison pills is also interesting. Of particular note for the former topic is Harrah's Entertainment $v$. JCC Holding Co. ${ }^{171}$ The case involved interpretation of a certificate provision giving specific shareholders the power to nominate a certain number of directors. The court wrote:

Because of the obvious importance of the nomination right in our system of

164. Frantz Mfg., 501 A.2d at 407.

165. Hollinger Int $' l, 844$ A.2d at 1080.

166. 883 A.2d 837 (Del. Ch. 2004).

167. 731 A.2d 818 (Del. Ch. 1999).

168. Jones Apparel Group, 883 A.2d at 846.

169. See Gen. DataComm Indus., 731 A.2d at 821 .

170. Id. at 821 . I have omitted two footnotes. The second of these quotes from the Hamermesh article at length on the openness of the law on point.

171. 802 A.2d 294 (Del. Ch. 2002). 
corporate governance, Delaware courts have been reluctant to approve measures that impede the ability of stockholders to nominate candidates. Put simply, Delaware law recognizes that "the right of shareholders to participate in the voting process includes the right to nominate an opposing slate." And, the unadorned right to cast a ballot in a contest for [corporate] office. . . is meaningless without the right to participate in selecting the contestants. As the nominating process circumscribes the range of choice to be made, it is a fundamental and outcome-determinative step in the election of officeholders. To allow for voting while maintaining a closed selection process thus renders the former an empty exercise. ${ }^{172}$

Even though this does not speak specifically to the question of proxy access, given the practical importance of proxy access to effective ability to nominate, the policy expressed in the passage clearly points in favor of allowing shareholder access to the corporate proxy. ${ }^{173}$

The leading case concerning the power of boards to adopt poison pills is Moran v. Household International. ${ }^{174}$ The Delaware Supreme Court held that boards had the power to adopt basic poison pills. ${ }^{175}$ The court relied mainly on section 157 to validate board power to enact pills, ${ }^{176}$ although it also briefly pointed to section 141(a) as "additional authority." the bylaws may regulate this power, however. Still, Moran, and the Unocal line of cases, does seem to grant boards quite broad authority to set antitakeover defenses.

Beyond these more specific cases, there are two broad lines of Delaware cases we should note, though they point us in opposite directions. First, many cases emphasize that section 141(a) (and its predecessors) grant boards broad authority to manage the business of a corporation. In Aronson v. Lewis, ${ }^{178}$ the Delaware Supreme Court said "[a] cardinal precept of the General Corporation Law of the State of Delaware is that directors, rather than shareholders, manage the business and affairs of the corporation." 179 The Aronson court also noted that "the demand requirement is a recognition of the fundamental precept that directors manage the business and affairs of corporations." 180 Even more significantly, "[t]he business judgment rule is an acknowledgment of the managerial prerogatives of Delaware directors under Section 141(a)."181 Thus,

172. Harrah's Entm't, 802 A.2d at 310-11 (citations omitted).

173. This case supports, at least to an extent, the argument by Mel Eisenberg cited above that corporate proxy access is vital to shareholder exercise of their core power to elect directors. See supra notes 115 through 116 and accompanying text; Eisenberg, supra note 115, at 1505-07.

174. 500 A.2d 1346 (Del. 1985).

175. "Basic" as opposed to dead hand or no hand pills, which are not valid. See Quicktum Design Sys. v. Shapiro, 721 A.2d 1281 (Del. 1998); Carmody v. Toll Bros., Inc., 723 A.2d 1180 (Del. Ch. 1998).

176. See Moran, 500 A.2d at 1351-52.

177. Id. at 1353 .

178. 473 A.2d 805 (Del. 1984).

179. Id. at 811 (citing DEL. CODE ANN. tit. $8, \S 141(\mathrm{a})$ ).

180. Id. at 812 .

181. Id. 
two of the key doctrines of Delaware jurisprudence, the business judgment rule and the demand requirement, are intimately tied to Section 141(a)'s grant of authority to the board.

In a similar vein, the case that created Delaware's intermediate standard of review for the adoption of antitakeover defenses also emphasized the grant of power to the board. "The board has a large reservoir of authority upon which to draw. Its duties and responsibilities proceed from the inherent powers conferred by Del. C. $\S 141$ (a), respecting management of the corporation's 'business and affairs." "182

Another line of cases points to the importance of shareholder voting as the leading basis for legitimizing board power. These cases tie back to the importance of the statutory grant, discussed above, to shareholders of the power to elect directors. ${ }^{183}$ The leading case in this line is Blasius Industries v. Atlas Corp. ${ }^{184}$ Chancellor Allen stated that " $[t]$ he shareholder franchise is the ideological underpinning upon which the legitimacy of directorial power rests." 185 Therefore, "matters involving the integrity of the shareholder voting process involve considerations not present in any other context in which directors exercise delegated power." 186 To protect shareholder power, the court announced that where the board has taken action for the primary purpose of thwarting a shareholder vote, it must present a compelling justification for such action. $^{187}$

Subsequent Delaware Supreme Court cases have not always strongly endorsed Blasius. In Stroud, for instance, the court seemed to cabin Blasius as a limited element within the Unocal standard of review. ${ }^{188}$ However, Blasius has survived and even thrived as a precedent for subsequent courts. Harrah's Entertainment is one example. Another important example is MM Companies v. Liquid Audio, Inc., in which the Delaware Supreme Court applied Blasius to invalidate a board bylaw that expanded the number of directors in response to a takeover-related proxy contest. ${ }^{189}$ Another is Chesapeake Corp. v. Shore, ${ }^{190}$ in which the Chancery Court struck down as inequitable a board bylaw that required a supermajority vote for shareholder bylaw amendments.

The Blasius line of cases supports an expansive understanding of the ability of shareholders to enact bylaws limiting board power. It provides particularly strong support for proxy access bylaws, as shareholding voting for directors is

182. Unocal Corp. v. Mesa Petroleum Co., 493 A.2d 946, 953 (Del. 1985).

183. See supra notes 115-16 and accompanying text; Eisenberg, supra note 115, at 1505-07.

184. 564 A.2d 651 (Del. Ch. 1988).

185. Id. at 659 .

186. Id.

187. See id. at 661-62.

188. See Stroud v. Grace, 606 A.2d 75, 92 n.3 (Del. 1992).

189. MM Cos. v. Liquid Audio, Inc., 813 A.2d 1118 (Del. 2003).

190. 771 A.2d 293 (Del. Ch. 2000). 
at the core of Blasius. Finally, a variety of recent Delaware cases suggest that the Delaware courts are taking a more skeptical view of board action, and are doing more to protect shareholders. ${ }^{191}$ This shift should make the courts more receptive to arguments favoring shareholder bylaws. Several extra-judicial comments by Delaware judges strongly point to the conclusion that those judges believe that proxy access bylaws are valid. ${ }^{192} \mathrm{I}$ am aware of no such evidence for poison pill bylaws, which remain more questionable, but even there it seems that Delaware courts today might be more receptive to such bylaws than Delaware courts five years ago.

Overall, legislative and judicial history do not clearly resolve the general tension between sections 141(a) and 109(b), nor do they resolve the more specific questions as to the validity of proxy access or poison pill bylaws. Both broad and narrow interpretations of the bylaw power find some support in the case law. Both text and case law point to a strong policy in favor of board authority, but both also point to shareholder voting as both a source of the legitimacy of that authority and as a potential limit on it. As with our textual analysis, proxy access bylaws receive greater support from the case law than poison pill bylaws.

\section{POLICY ANALYSIS OF BYLAWS}

In this section I turn to a policy analysis of what matters we should allow bylaws to regulate. Policy matters for at least two reasons. First, as the Eskridge and Frickey funnel suggests, ${ }^{193}$ judges frequently take policy into account in interpreting statutes. They differ as to how much weight they give policy concerns and as to how explicit they are in considering policy, but most judges do consider it. The analysis of text, legislative history, and court cases yields enough indeterminacy, at least with respect to poison pill bylaws, that policy concerns are likely to receive a lot of attention from courts faced with these issues. That analysis also suggests broad policy concerns embedded in the statutory text and recognized by the courts, so that further analysis of how to advance those goals is a fitting extension of the analysis of the previous section. Second, we independently care about the policy effect of how corporate law statutes are interpreted. If the more strictly legal analysis suggests one result but a policy analysis suggests a different result, that is interesting for purposes of future revision of the statutes even if the policy concerns do not affect how a court interprets the current statutes.

191. See id. at 325-28. The leading cases are Omnicare v. NCS Healthcare, 818 A.2d 914 (Del. 2003); In re The Walt Disney Co. Derivative Litigation, 825 A.2d 275 (Del. Ch. 2003); and In re Oracle Corp. Derivative Litigation, 824 A.2d 917 (Del. Ch. 2003). But see In re Walt Disney Co. Derivative Litigation, No. Civ.A. 15452, 2005 WL 2055651 (Del. Ch. Aug. 9, 2005).

192. See Alison Carpenter, Delaware Chancery Jurists Tell Investors to Be Creative, Do More if They Want Power, 2 CORP. ACCOUNTABILITY REP. 351 (2004).

193. See supra note 34 and accompanying text. 
A policy analysis of corporate bylaws could potentially draw on many different methodologies and consider the effect of competing rules on many different goals or values. I shall narrow the scope of my analysis in a conventional way by limiting myself to an economic analysis focused mainly, if not quite entirely, on efficiency as a goal. This has become the standard approach within corporate law scholarship focused on normative questions, so although it can certainly be questioned, I will not question it here.

Even within this accepted general approach, analysts have differed significantly as to what economic efficiency entails in setting corporation law. The key difference I wish to flag here concerns whose interests the law should treat a corporation as serving. The overall goal of corporation law is to have corporations maximize the net social wealth that each corporation creates. The prevailing view in the U.S. has been that this can be best accomplished if the directors and officers of a corporation seek to maximize shareholder value. ${ }^{194}$ The case law typically supports this view, both in Delaware ${ }^{195}$ and in other states. ${ }^{196}$ However, a significant minority in the U.S., and a majority in some other countries, believe that the board and officers should consider and attempt to advance the interests of a variety of stakeholders, including shareholders but also employees, creditors, and various others. ${ }^{197}$ Both courts and statutes do sometimes allow the consideration of other constituencies, though it is not clear that such consideration can be allowed to significantly hurt shareholder interests. ${ }^{198}$ The arguments for and against an expansive bylaw power differ significantly depending on whether one takes the narrower view of shareholder primacy or the broader stakeholder approach. In this section I shall first start with the arguments that assume a shareholder primacy norm, as that position dominates in American scholarship and case law. However, I shall also consider how the arguments differ if one takes a stakeholder approach, since I

194. See, e.g., FranK H. EASTERBrooK \& DANiel R. Fischel, THE ECONOMIC STRUCTURE of CORPORATE LAW 38 (1991); Henry Hansmann \& Reinier Kraakman, The End of History for Corporate Law, 89 GEO. L.J. 439 (2001); Jonathan R. Macey, An Economic Analysis of the Various Rationales for Making Shareholders the Exclusive Beneficiaries of Corporate Fiduciary Duties, 21 STETSON L. REV. 23 (1991); STEPHEN M. BAINBRIDGE, CORPORATION LAW AND ECONOMICS 410-29 (2002).

195. The clearest area where Delaware courts recognize shareholder primacy is in circumstances invoking the Revlon duty. See Revlon, Inc. v. MacAndrews \& Forbes Holdings, Inc., 506 A.2d 173 (Del. 1985).

196. The canonical cite is Dodge v. Ford Motor Co., 170 N.W. 668 (Mich. 1919).

197. See E. Merrick Dodd, Jr., For Whom Are Corporate Managers Trustees?, 45 HARv. L. Rev. 1145 (1932); Kent Greenfield, The Place of Workers in Corporate Law, 39 B.C. L. REV. 283 (1998); Marleen A. O'Connor, Restructuring the Corporation's Nexus of Contracts: Recognizing a Fiduciary Duty to Protect Displaced Workers, 69 N.C. L. REV. 1189 (1991); Lynn A. Stout, Bad and Not-So-Bad Arguments for Shareholder Primacy, 75 S. CAL. L. REV. 1189 (2002).

198. For the expressed views of the Delaware courts, see Unocal Corp. v. Mesa Petroleum Co., 493 A.2d 946 (Del. 1985); Revlon, Inc. v. MacAndrews \& Forbes Holdings, Inc., 506 A.2d 173 (Del. 1986). Many states, though not Delaware, have corporate constituency statutes that allow boards to consider the interests of constituencies other than shareholders. See Brett H. McDonnell, Corporate Constituency Statutes and Employee Governance, 30 WM. MITCHELL L. REV. 1227, 1232-41 (2004). 
follow that approach, for reasons I shall outline briefly below. ${ }^{199}$

\section{A. Arguments Assuming Shareholder Primacy}

An expansive interpretation of the bylaw power increases shareholder power within the corporation because shareholders are able to amend the bylaws without board approval or initiative. Certificate amendments, in contrast, are initiated by the board and require board approval. Thus, if one asks whether the bylaw power should be interpreted expansively, and if one assumes, as we are for now, that our goal is to maximize shareholder wealth, an obvious answer suggests itself. If shareholders wish to set the rule on a certain topic, they should be able to do so. The corporation is supposed to be advancing their interests, and they can judge what rules are best for them.

Consider the most obvious counter-argument and its corollary caveat. In a public corporation with a large number of shareholders most if not all of whom own a small percentage of the corporation's shares, it makes no sense for shareholders to engage in ordinary decision making. The shareholders, most of whom do not work in the corporation, lack easy access to much useful information, and their small shareholdings give them little incentive to acquire more information. Even if they had the needed information, they would have to agree on what to do, and the costs of collective decision making would be high. ${ }^{200}$ Thus, it is much more efficient for boards, or in most cases for corporate officers under board supervision, to make ordinary business decisions. Indeed, the advantages of centralized decision making are one of the key attractions of the corporate form. ${ }^{201}$ Corporate law provides a set of off-therack rules that provide a basic hierarchical structure. ${ }^{202}$ The law provides an allocation of intra-corporate power in which shareholders are involved in very few decisions, and in most cases this allocation makes eminent good sense. Section 141(a) and its analog in other states is an important part of that allocation of corporate power, as the case law has recognized.

Few if any people in the bylaw debate, or more generally the corporate governance debate, would contest that point. Yet, the point does not end the debate for two reasons. First, most advocates of an extensive interpretation of the bylaw power do not argue for its extension without limit. Instead, they argue that bylaws are mainly appropriate in matters of corporate governance, or procedural issues. ${ }^{203}$ Shareholders in public corporations will not be involved in ordinary business decisions. The general advantage of centralized decision making does not deny that shareholders should have some role in corporate

199. See infra Part IV.B.

200. See HENRY HANSMANN, THE OWNERSHIP OF ENTERPRISE 89-92 (1996).

201. See BAINBRIDGE, supra note 194, at 201-03.

202. See EASTERBROOK \& FISCHEL, supra note 194, at 34.

203. See the distinctions discussed supra Part III. 
governance.

Second, and more crucially, what exact distribution of powers is optimal may differ from corporation to corporation. Corporate law can at best provide rules that work well for most companies in most circumstances. This suggests that if enough of the relevant affected parties can agree, then corporations should be able to diverge from the general rules allocating powers within corporations.

Section 141(a) and its analogs are default rules. It is clear that the certificate can vary the grant of power to the board. Thus, if a majority of both shareholders and directors agree, they can amend the certificate to limit the managerial power of the board. This reflects the benefits of having a default rule that can be varied where individual circumstances make the general rule unattractive.

Thus, at two ends this topic is largely uncontested. As a general rule, applying most of the time to most questions, boards, not shareholders, have and should have authority to make ordinary business decisions. On the other hand, the board and shareholders together can agree to limit that usual board authority if they choose to do so in the certificate.

The debate occurs in between these two extremes: can shareholders alter the usual allocation of power through the bylaws rather than the certificate? The key difference, of course, is that amending the bylaws does not require board approval. Thus, the debate is not over what the default rule should be, or whether that rule should be mandatory rather than default. Instead, the debate is over how a corporation should be able to opt out of the default rule of broad board authority.

Allowing the bylaws to regulate a matter creates a rather nuanced and complicated opt-out mechanism. Saying that the bylaws may regulate matter $X$ means, as a default matter of corporate law, that shareholders by a majority vote, on their own initiative, may set the rules for how their corporation handles matter $X$, thus varying from what the default legal rules for matter $X$ would dictate. However, the corporation may in turn vary that mechanism for opting out in various ways. As a default matter only shareholders may change the bylaws, but the certificate may, and typically does, give that power to the board as well. ${ }^{204}$ As a default, holders of a majority of the outstanding shares constitute a quorum, and the vote of a majority of a quorum of shareholders is sufficient to enact a bylaw, but either the certificate or the bylaws may vary those requirements. ${ }^{205}$ Finally, and most importantly for the following argument, a corporation can take matter $X$ out of the bylaw power by setting the

204. See DEL. CODE ANN. tit. 8, $\S 109$ (a) (2005). However, the certificate may not deny the shareholders power to amend the bylaws. See id.

205. See id. $\S 216$. 
rules for matter $X$ in the certificate. ${ }^{206}$ The bylaws are subordinate to the certificate and may not contain any provision inconsistent with the certificate. ${ }^{207}$ Thus, even if the corporate law gives shareholders the power of initiative over matter $X$ by allowing the bylaws to regulate matter $X$, the shareholders may agree to tie their hands on matter $X$ through a certificate provision, so that future changes to that rule require board as well as shareholder approval.

Our question is over what matters should shareholders have a qualified power of initiative. Our discussion so far demonstrates that the scope of the bylaw power rule is a default rule as to how the corporation shall opt out of various default rules. In thinking about this topic, we might get help from the literature on majoritarian and minoritarian default rules. ${ }^{208}$ Most early law and economics thinking about how to set legal default rules argued for a majoritarian approach: choose the rules that a majority of the regulated agents would choose if they could make a costless choice under conditions of zero transaction costs. ${ }^{209}$ However, in a landmark article Ian Ayres and Robert Gertner argued ${ }^{210}$ that sometimes it might make sense to instead set penalty default rules, to encourage persons with private information to reveal that information to the court or to those with whom they contract, even though the default rules so set might not be what most parties would choose if contracting were costless.

Would the aggregated interests of shareholders and managers in most corporations be helped or hurt by giving shareholders a broad power to regulate corporate governance through bylaws? The key benefit from shareholder power of initiative emerges if we consider the agency problem that centralized management creates. We have considered the great benefits that such centralization creates. However, such benefits come at a cost. Centralized management separates ownership from control: shareholders are the intended beneficiaries of corporate decision making, but the officers and directors do the actual decision making. There is nothing to ensure that they will make decisions in the best interests of shareholders.

A variety of legal and non-legal mechanisms help keep directors and officers in line. These include the threat of hostile takeovers, high-incentive executive compensation, the managerial labor market, product markets, norms, shareholder voting, and shareholder suits for breaches of fiduciary duties. Note

206. The certificate may contain any provision that may be included in the bylaws. See id. $\S$ 102(b)(1).

207. See id. §109(b).

208. See Ian Ayres \& Robert Gertner, Majoritarian vs. Minoritarian Defaults, 51 STAN L. REV. 1591 (1999).

209. See Ian Ayres \& Robert Gertner, Filling Gaps in Incomplete Contracts: An Economic Theory of Default Rules, 99 YALE L.J. 87, 89-90 (1989).

210. See id. 
that shareholder selling (with its effects on stock price), shareholder voting, or both are crucial to many of these mechanisms. As Robert Thompson and Gordon Smith have emphasized in an insightful article on "sacred space," shareholder oversight is crucial to maintaining and constraining board power in various economic theories of the firm. ${ }^{211}$ The Blasius line of cases recognizes the importance of this shareholder role. ${ }^{212}$

The corporate governance provisions of a corporation's certificate and bylaws should try to reduce incentives to engage in opportunistic behavior while still providing the board and officers with the flexibility and authority they need to run the business effectively. However, there is an obvious danger that the directors may be able to block shareholders from putting desirable provisions into the certificate. ${ }^{213}$ Thus, allowing shareholders to put corporate governance provisions in place without board approval has clear attractions. Since directors are part of the problem that shareholders may be trying to control, it would seem to make little sense to give those very same directors a veto power over what controls shareholders can place on them. Shareholders should be able to take self-help action to defend their right to sell shares to outside bidders and to choose the board of directors. ${ }^{214}$

We can see the point in more detail if we consider the two types of bylaws that are our focus, shareholder proxy access bylaws and poison pill bylaws. Shareholder voting for directors is a potentially important limit on director opportunism. Voting rules can also affect the market for corporate control. However, without access to corporate proxy materials, contested elections will be prohibitively expensive for challengers except in the context of hostile takeovers. Thus, shareholder voting for directors will have little effect as a control on opportunism except insofar as it facilitates hostile takeovers.

Similarly, poison pill bylaws could bolster the effectiveness of a key limit on opportunism, the threat of hostile takeovers. Poison pills are an important defense against takeovers which the board does not want. The poison pill combined with a staggered board and a ban on shareholder removal of directors

211. See Robert B. Thompson \& D. Gordon Smith, Toward a New Theory of the Shareholder Role: "Sacred Space" in Corporate Takeovers, 80 TEX. L. REV. 261, 299 (2001).

212. See id. at 299 n. 183 .

213. There is an argument that at the time a corporation goes public its certificate will contain the optimal mix of provisions, as those owning the shares at that time will bear the costs of bad provisions, since buyers will pay less for shares in a corporation burdened by poor corporate governance practices. See Michael Jensen \& William Meckling, Theory of the Firm: Managerial Behavior, Agency Costs, and Ownership Structure, 3 J. FIN. ECON. 305 (1976). However, there is much debate over whether IPO markets work so efficiently in practice. See Michael Klausner, Institutional Shareholders, Private Equity, and Antitakeover Protection at the IPO Stage, 152 U. PA. L. REV. 755 (2003); Lucian Arye Bebchuk, Why Firms Adopt Antitakeover Arrangements, 152 U. PA. L. REV. 713 (2003). Moreover, even if the certificate is efficient at the time a corporation goes public, over time it may cease to be efficient. See EASTERBROOK \& FISCHEL, supra note 194, at 32-34.

214. See Thompson \& Smith, supra note 211 , at 322-23. 
without cause makes hostile takeovers extraordinarily difficult and unlikely. ${ }^{215}$ Poison pill bylaws allow shareholders to stop boards from erecting such a powerful defense, if a majority of shareholders believe that defense is bad for them.

That, then, is the core argument in favor of allowing bylaws to regulate corporate governance under a majoritarian default rule approach: most corporations would prefer to give shareholders broad bylaw powers as a potential way of limiting managerial opportunism. This argument supports the core distinction between corporate governance and ordinary business matters that emerged from the doctrinal analysis of the previous section.

The minoritarian approach to default rules has identified several reasons why one might want to set default rules in a way that might not reflect what most parties would choose in a world of costless contracting. The original reason focused on encouraging parties to a contract to reveal useful private information. ${ }^{216}$ This argument might apply in our setting. Boards and officers are the parties in the corporate contract most likely to have relevant private information. In particular, they are most likely to know both the idiosyncratic private benefits and the costs of unchecked managerial power in their particular company. We might then want to force them to reveal that stronger power is particularly important in their company by putting limits on the bylaw power into the certificate.

Perhaps even more helpful to us is another argument for minoritarian defaults. It may be easier to contract around some defaults than others. If so, it may make sense to set a default that is easier to contract around, so that parties will be more likely to do so when the default is inefficient. ${ }^{217}$ This also argues for a broad bylaw power. It is easier for managers to contract around the default rule by amending the certificate than for shareholders, since only managers have the power to initiate changes in the certificate. It might therefore make sense to force boards to narrow the statutory default of a broad bylaw power, even if it turns out that most corporations do choose to do so. If a weak bylaw power is the statutory default, shareholders are likely to have much trouble in convincing boards to amend the certificate to strengthen shareholder power, particularly in already-public corporations. ${ }^{218}$

215. See Bebchuk et al., supra note 10.

216. See Ayres \& Gertner, supra note 208.

217. See id. at $1600-04$.

218. Lucian Bebchuk and Assaf Hamdani have argued along these lines that corporate law default rules generally should be set in a way that is more rather than less restrictive of management, because corporations are more likely to opt out of inefficient rules that overly-restrict the board than of inefficient rules that underly-restrict it. See Lucian Arye Bebchuk \& Assaf Hamdani, Optimal Defaults for Corporate Law Evolution, 96 Nw. U. L. REV. 489, 492-93 (2002). They specifically apply their approach to the question of poison pills. Their preferred answer is that the law should not allow management to adopt a poison pill without shareholder ratification. See id. at 514. Failing that, though, they suggest allowing shareholders to adopt bylaws that limit the board's ability to adopt a pill. See id. at 518. The more general issue here is the optimal "stickiness" of a default rule, an important topic which 
The remaining question is whether any counter-arguments caution against a default power of shareholder initiative in setting rules of corporate governance. One leading counter-argument holds that shareholders lack the information they need to make informed corporate governance decisions. This is a good reason for the default rule that boards, not shareholders, are responsible for ordinary business decisions. Some argue that even in setting general rules about corporate governance shareholders in public corporations will not be wellenough informed to make good decisions.

Shareholders will usually be less knowledgeable than directors, and particularly than officers. However, shareholders are also more likely to have their own best interests at heart in voting on corporate governance rules than are directors and officers. ${ }^{219}$ Moreover, many corporate governance issues, including poison pills and shareholder proxy access, are likely to arise at many different corporations, raising the same general questions at each, albeit with some company-specific variations. Shareholders are likely to be rather wellinformed on such issues. ${ }^{220}$ That is particularly so for institutional investors, which hold over half of all the shares in public U.S. corporations.

Another problem facing shareholder voting on bylaws is free riding and rational apathy. Even if the SEC changes its rules and allows shareholders to include proxy access and/or poison pill bylaws as shareholder proposals, there will still be costs associated with making shareholder proposals. ${ }^{221}$ Any single shareholder will gain only a small fraction of those benefits. Even if the costs of the proposals are relatively modest, they may be enough to induce all shareholders to avoid making the relevant proposals. Moreover, even after the proposals are made, rational apathy may induce a majority of shareholders to fail to investigate before voting and instead simply side with management. Thus, shareholder bylaws may have little practical effect because shareholders will rarely use the new tool at their disposal.

It does seem plausible that shareholders will not exercise the bylaw power frequently. However, this counterargument does not effectively caution against allowing corporate governance bylaws, for several reasons. Shareholders do already make shareholder proposals, with growing frequency. Nowadays many proposals focused on corporate governance receive majority approval. That happens even though most proposals today are merely advisory, and boards can and frequently do ignore them. With mandatory bylaw proposals having greater

has not received enough attention. For what is still to my knowledge the best general discussion of that topic, see Ayres \& Gertner, supra note 208, at 120-27.

219. There is still some concern about special interest shareholders. See infra notes 223-26 and accompanying text.

220. See Lucian Arye Bebchuk, The Case for Increasing Shareholder Power, 118 HARV. L. REV. 833 (2005); Eisenberg, supra note 115, at 1510.

221. See Robert Pozen, Institutional Perspective on Shareholder Nominations of Corporate Directors, 59 BUS. LAW. 95 (2003). 
effect, shareholders would have more reason to expend the costs necessary to propose them. This particular argument only suggests that shareholder proposals will be infrequent; however, it does not indicate any problems with those proposals that actually do pass. ${ }^{22}$

Another counter-argument is the threat of special interest bylaws. That is, shareholders with special interests at variance with those of other shareholders and the corporation may try to use bylaw proposals to extract private benefits from management. ${ }^{223} \mathrm{~A}$ particular concern has been the role of union and governmental pensions, which critics believe have tried to use the shareholder proposal mechanism for political ends. ${ }^{224}$ However, we can trust the board to argue strongly against such proposals. ${ }^{225}$ Union and governmental pensions win on such proposals only when they propose general corporate governance measures that have no clear special advantages to them, such as advisory proposals to end staggered boards or poison pills. ${ }^{226}$ Unions and public sector pensions are playing a strongly positive role in overcoming the free rider problem among shareholders. Other large institutional investors are unwilling to shoulder the costs of making shareholder proposals, because they do not realize the benefits. Union and public sector pension managers are willing to bear those costs.

Jeffrey Gordon has drawn on social choice theory to suggest another potential problem with shareholder initiative power. If shareholders have differing views on an array of different possible voting matters, then under some circumstances vote cycles may be possible. That is, shareholder may prefer proposal A to B, and B to C, but prefer C to A. Decision making could then become incoherent and chaotic. ${ }^{227}$ This could be a problem for boards as well, which are also a collective body, but there are far fewer directors than shareholders in a public corporation, and discussion among directors is more likely to lead to a consensus or near-consensus choice than among shareholders.

Although this is a theoretical possibility, it has never struck me as likely to be a very major practical problem for most corporations. Most shareholders agree on their basic aim: to maximize share value. The kinds of conflicting goals that plague political choices are far less present among shareholders. There is an extensive literature on conditions under which shareholders would

222. See Bebchuk, supra note 220, at 43.

223. See Stephen Choi \& Andrew Guzman, Choice and Federal Intervention in Corporate Law, 87 VA. L. REV. 961 (2001).

224. See Roberta Romano, Public Pension Fund Activism in Corporate Governance, 93 CoLUM. L. REV. 795 (1993).

225. See Bebchuk, supra note 220 , at 46 ; Stewart J. Schwab \& Randall S. Thomas, Realigning Corporate Governance: Shareholder Activism by Labor Unions, 96 MICH. L. REV. 1018 (1998).

226. See Schwab \& Thomas, supra note 225.

227. See Jeffrey N. Gordon, Shareholder Initiative: $A$ Social Choice and Game Theoretic Approach to Corporate Law, 60 U. CIN. L. REV. 347 (1991). 
be unanimous. ${ }^{228}$ These conditions are unlikely to hold strictly in life, but we do not need unanimity to avoid voting cycles. Single-peaked preferences, for instance, are a sufficient condition to avoid cycling. ${ }^{229}$ Indeed, one of the best argument in favor of allowing shareholders but not other constituencies such as employees ultimate voting power within a corporation is precisely that shareholders are less likely to disagree, so that the costs of collective action are likely to be a lot less. ${ }^{230}$

Finally, even if cycling is a serious practical problem, various mechanisms can help reduce the problem. ${ }^{231}$ Bebchuk suggests that management counterproposals could do the trick. ${ }^{232}$ Advance notice bylaws may also reduce the problem, by limiting the ability of competing parties to strategically launch competing proposals. Limits on the ability of shareholders to call special meetings also serve this purpose.

A final set of counter-arguments to a shareholder power of initiative through bylaw amendments concerns various proffered reasons why shareholders might profit from pre-commitment. Just like Ulysses binding himself to the mast to prevent him from yielding to the temptation of the Sirens, ${ }^{233}$ shareholders could be better off if they prevent themselves from interfering with board decisions.

Scholars have suggested several reasons why this might be so. Marcel Kahan and Edward Rock suggest that antitakeover provisions in the charter may help boards negotiate a better price in an acquisition than shareholders would be able to achieve on their own. ${ }^{234}$ If shareholders can choose to sell on their own, collectively, without board interference, that will create an auction mechanism, but Kahan and Rock argue that a negotiation mechanism may be better for selling corporations. ${ }^{235}$ Shareholders may receive a higher value if they allow antitakeover provisions to prevent them from interfering with the board's negotiations.

Note that by Kahan and Rock's own admission, this does not mean that shareholders are always better off with antitakeover provisions. Even if the board can negotiate a better price for shareholders, that does not always mean it will. Opportunistic directors may use antitakeover provisions to prevent valueenhancing acquisitions that would hurt them personally, or may use their

228. See Harry DeAngelo, Competition and Unanimity, 71 AM. ECON. Rev. 18 (1981).

229. See Bebchuk, supra note 220 , at 55; DUNCAN BLACK, THE THEORY OF COMMITTEES AND ELECTIONS 18 (1958).

230. See HANSMANN, supra note 200.

231. The social choice literature discusses these mechanisms under the term "structure-induced equilibria."

232. See Bebchuk, supra note 220 , at 55-56.

233. See JON ELSTER, UlYSSES AND THE SIRENS (1979).

234. See Kahan \& Rock, supra note 12.

235. See id. at 5-8. 
negotiating powers primarily to negotiate a deal that benefits them rather than the shareholders they represent. Thus, in some circumstances shareholders may be better off with no or limited antitakeover provisions. ${ }^{236}$ It is an empirical question whether antitakeover provisions help shareholders in any particular corporation.

Here, though, we need not argue over the empirical details surrounding their argument. Nothing in the bylaw debate calls into question Kahan and Rock's "Madisonian" approach. ${ }^{237}$ Even if states were to allow shareholders to regulate poison pills in the bylaws, we have already seen that corporations may in turn limit that shareholder power if they so choose. Most significantly, if the shareholders agree, they can build a poison pill into the certificate, or, more modestly, enact a certificate provision that removes the ability of bylaws to regulate poison pills. The certificate trumps the bylaws. Thus, if shareholders in a corporation are persuaded by Kahan and Rock's argument that they are best off binding themselves like Ulysses not to interfere, they could still do so. They only difference is that under the expansive bylaw regime they would have to more explicitly choose to do so. That may well make sense, though, given the dangers of board entrenchment. If shareholders are better off binding themselves, then let them explicitly make that decision.

Jennifer Arlen and Eric Talley present a different, rather broader and more insidious reason for being skeptical about shareholder initiative power. ${ }^{238}$ Directors and officers have many different means available to protect against takeovers. Even if shareholders could on their own initiative block some of these, such as poison pills, they could not block them all. Many defenses are embedded within ordinary business decisions that shareholders cannot effectively control. For instance, contracts with third parties may contain change-of-control provisions that make takeovers more expensive, or spin-offs and strategic acquisitions may deter tender offers. ${ }^{239}$ If shareholders block officers from some defenses, they may shift instead to these unregulable defenses. But those unregulable defenses may be more costly to shareholders than more visible defenses, and hence it may be in the best interest of shareholders not to regulate even those defenses that they can. ${ }^{240}$

There are several responses to Arlen and Talley. One sort of response takes issue with their empirical judgments. Several factors may lessen the problem

236. See id. at 14-15.

237. They compare their approach to two alternatives. The "Hamiltonian" approach strongly favors board authority over takeover bids. The "Jeffersonian" approach strongly favors shareholder approach. Their preferred "Madisonian" approach recognizes that for some corporations board authority may be best, while for others shareholder authority may be best, and focuses instead on allowing each corporation to achieve its own tailored solution through corporate charter provisions. See id. at 11-15.

238. See Jennifer Arlen \& Eric Talley, Unregulable Defenses and the Perils of Shareholder Choice (USC Law, Olin Research Paper 03-7, Apr. 2003), available at http://www.ssm.com/abstract=398600.

239. See id.

240. See id. 
they identify. Unregulable defenses may be less costly to shareholders than regulable defenses. Or, they may be so costly to the corporation that directors and officers may not shift to them even if they can no longer use their current defenses. Or, some unregulable defenses may already be so widespread that there is not much room left for expanded use of them. A combination of such factors may imply that at least for most public corporations shareholder initiative power is still attractive.

Their relatively modest claim is that "an immutable, one-size-fits-all shareholders choice rule is unlikely to improve shareholders' welfare."241 But shareholder initiative power in the bylaws does not create an immutable, onesize-fits-all shareholder choice rule. Shareholders may use the bylaws to tailor what sort of matters they will vote on. More importantly, if convinced by Arlen and Talley that the bylaw power will lead to an unhealthy shift to other defenses, shareholders can amend the certificate to eliminate the bylaw power that they find objectionable. ${ }^{242}$ Thus, where shareholder choice is objectionable, a bylaw-centered approach does not require corporations to allow shareholder choice.

Stephen Bainbridge has made perhaps the broadest set of arguments against a shareholder power of initiative. ${ }^{243}$ The key advantage of centralization is that it is impossible, or at least prohibitively expensive, to contract in advance over all possible contingencies. Some things will happen that the corporate contract simply does not address, and someone must have the power to decide what to do in such cases. ${ }^{244}$ Corporate managers can do the job much more efficiently.

As we have seen, this creates a new agency problem. Bainbridge argues that having a small collective body, the board, overseeing the managerial hierarchy is the best solution to this problem. The board has the ultimate power to make decisions dealing with new events. Bainbridge frequently draws on the wonderful work of Ken Arrow on organizations ${ }^{245}$ to note that giving the unlimited power of review over one party's decision making ultimately pushes back the authority to the reviewing party. Arrow notes a tradeoff between authority and responsibility: we need decision makers with authority to make decisions quickly and efficiently, but we also need some mechanisms of

241. Id. at 1 .

242. The campaign to limit the bylaws for this reason could be a bit tricky. The board should avoid just baldly saying "If you take away the poison pill we will put in other provisions that you can't stop and that are even worse for you." A Delaware court might well react badly to such a threatened violation of the board's fiduciary duty. See Lacos Land Co. v. Arden Group, Inc., 517 A.2d 271 (Del. Ch. 1986). Still, well-counseled boards should find non-objectionable ways to make the point and get the certificate amended.

243. See BAINBridge, supra note 194, at 197-99, 516-17; Stephen M. Bainbridge, Director Primacy: The Means and Ends of Corporate Governance, 97 Nw. U. L. REV. 547 (2003).

244. See BAINBRIDGE, supra note 194, at 201; Ronald Coase, The Nature of the Firm, 4 ECONOMICA 386 (1937).

245. See Kenneth J. ArRow, The Limits of Organization (1974). 
responsibility that hold those decision makers accountable to the interests of those who are supposed to benefit from their decisions. ${ }^{246}$

In response to suggestions of enhanced shareholder power, Bainbridge repeatedly turns to this authority/responsibility tradeoff. Greater accountability to shareholders will reduce managerial authority, decreasing the gains we get from such authority. These lost gains from authority are a bad thing, hence increased shareholder power is a mistake. ${ }^{247}$

However, Bainbridge's argument does not prove his point. Let us take as true the authority/responsibility tradeoff, and also the assumption that increased responsibility will lead to decreased authority. ${ }^{248}$ The fact that there is a tradeoff does not tell us whether we are at the most socially desirable point currently in making that tradeoff. It will take detailed, hard analysis, and a tough policy judgment, to evaluate it. After all, most proposals realistically on the table today do not move to a radical world of all responsibility, no authority. Certainly an expanded understanding of the bylaw power is very far from moving to such a radical world. To convince us that expanded responsibility is not desirable, Bainbridge would have to argue, among other things, that the current system already does a good enough job of constraining managerial opportunism. Although Bainbridge does point to the standard economists' arguments for current constraints on such opportunism, he does not do so in a convincing-enough way to make his point.

This is particularly so in the case of the bylaw debate. If shareholders do not think it is appropriate for their corporation, they can structure the certificate to suitably limit the bylaw power. Bainbridge is enough of a contractarian that he should agree that shareholders should be able to opt out of the strong director primacy that he advocates as the norm. ${ }^{249}$ The debate then boils down to how this opt-out mechanism should work. Bainbridge's broad arguments do not give us much reason to choose between the moderately different opt-out regimes of weak and strong bylaw power.

Those are the most important of the general arguments for and against a degree of shareholder power to take initiative in setting matters of corporate governance. ${ }^{250}$ Although some of the arguments give some good, albeit not

246. See id.

247. See BAINBRIDGE, supra note 194, at 517.

248. This assumption will not be true in all situations, by the way, even accepting the basic tradeoff. The assumption amounts to assuming that we are on the efficiency frontier of the authority/responsibility tradeoff, so that more responsibility means less authority. In many cases, we will instead be away from the efficient frontier, so that it is possible to achieve greater responsibility without any loss in authority.

249. On Bainbridge' contractarianism, see BAINBRIDGE, supra note 194, at 199-200.

250. The recent debate over shareholder proxy access contains some more specific arguments against such access, including diversion of resources, balkanized boards, and deterring qualified persons from serving as directors. See Martin Lipton \& Steven A. Rosenblum, Election Contests in the Company's Proxy: An Idea Whose Time Has Not Come, 59 BUS, LAW. 67 (2003). Lucian Bebchuk has answered these points quite effectively, so I will not repeat those answers here. See Lucian Arye 
irrefutable, reasons to avoid some strong suggestions of shareholder choice, none of them provide good reasons for opposing the modest degree of shareholder choice we could achieve through an expansive interpretation of the bylaw power to allow for bylaws regulating general matters of corporate governance. Such a modest power provides at least some promise of helping shareholders to limit some of the worst excesses of opportunistic directors and officers.

It may well be that this move does not go nearly far enough. The ability to propose and adopt bylaws will have much less practical value if shareholders must solicit proxies on their own to pass such bylaws. Access to the corporate proxy materials is as crucial to the prospect of creating bylaws as it is to the prospect of shareholders nominating directors. Section $\mathrm{V}$ shall address that issue. But first, we must re-examine the basic policy questions while dropping the assumption of shareholder primacy.

\section{B. Arguments Assuming a Stakeholder Approach}

The previous sub-section took as given the shareholder primacy norm that dominates most American corporate law and scholarship. I do not personally accept that norm, however. I adopt a stakeholder approach-corporations should be run to advance the interests of several important stakeholder groups involved in the corporation. The most important stakeholder group other than shareholders and managers is employees, with creditors also of some importance. $^{251}$

The standard intuition supporting shareholder primacy is that shareholders own the corporation, and hence it should be run in their interest. That intuition does not survive the nexus of contracts approach, or more broadly the economic approach, that has come to dominate corporate law scholarship over the last few decades. Shareholders are just one of a number of groups that contracts with the other groups through the corporate legal form. Shareholders provide one input of some, but not decisive, importance, namely equity (as opposed to debt) financing. They get certain rights of control in return, which under current law fall rather short of standard ownership rights. The basic theory does not give shareholders a privileged position. Those arguments do

Bebchuk, The Case for Shareholder Access to the Ballot, 59 Bus. LAw. 43 (2003). In addition to Bebchuk's arguments, note that, in contrast to the SEC's proposed proxy access regime, the bylaw approach allows shareholders to opt out of the ability to achieve proxy access by so providing in the certificate, a further safeguard for those who think that such access is bad for shareholders. Given this opt-out, opponents of proxy-access bylaws must argue not only that such access is bad, but that shareholders will for some reason be unable to understand those arguments and protect themselves by either just voting down bad bylaws or, more strongly, by preventing proxy access in the certificate.

251. Some advocates of a stakeholder approach sweep more broadly than this, including customers, suppliers, local communities, and even the environment as relevant stakeholders. Corporate constituency statutes typically include many of those groups as well. However, the argument presented in the text focuses only on employees. 
not convince me, though; for the remainder of this Section, I assume that corporate law should promote the interests of a variety of stakeholders, not just shareholders.

To someone who believes that employees have a major interest at stake in the firm, the first-best solution might well be to give employees some power in employee governance. ${ }^{252}$ That is not a politically plausible prospect in the United States today. Thus, stakeholder advocates must argue within a secondbest world where corporate governance rules divide power between shareholders, directors, and officers. The question in that world is as follows: would employees (or other stakeholders one may care about) be better off with a shift in power from the status quo to greater shareholder power, a shift to greater board power, or is the status quo as good as it gets? If we view corporations as a game involving managers, shareholders, and employees, then the different groups' interests converge and diverge in complex ways, with different alliances possible. ${ }^{253}$

Some scholars with sympathies towards employees and other stakeholder groups have argued against the contemporary push for greater shareholder power, and replied that a return to a more managerialist regime would be better for employees and other non-shareholder stakeholders. ${ }^{254}$ On some matters, at least, it does seem that employees have more in common with managers than with shareholders. For instance, in many cases hostile takeovers may threaten the jobs of both managers and employees. ${ }^{255}$ More generally, both managers and employees may have significant firm-specific human capital tied up in the corporation, making exit hard. Neither managers nor employees can diversify their jobs in the way that shareholders can diversify their portfolios. This may make managers and employees prefer less risky projects than shareholders would prefer. Officers who work daily with employees may come to identify with those employees in ways that they do not with absent shareholders.

On the other hand, in other matters the interests of employees may align more closely with those of shareholders. For instance, managers may use their power to pursue private benefits that decrease the corporate surplus available to both shareholders and employees. Thus, on the question of executive compensation employees and shareholder may have a shared cause. Even on the subject of acquisitions, frequently managers may oppose bidders who threaten their personal power even when the acquisition would be a real boon

252. See McDonnell, supra note 198.

253. See id; John C. Coffee, Jr., Unstable Coalitions: Corporate Governance as a Multi-Player Game, 78 GEO. L.J. 1495 (1990).

254. See LAWRENCE E. MITCHELl, CORPORATE IRRESPONSIBILITY: AMERICA'S NEWEST EXPORT (2001); Margaret M. Blair \& Lynn A. Stout, Director Accountability and the Mediating Role of the Corporate Board, 79 WASH. U. L.Q. 403 (2001).

255. See Andrei Shleifer \& Lawrence H. Summers, Breach of Trust in Hostile Takeovers, in CoRPORATE TAKEOVERS: CAUSES AND CONSEQUENCES (Alan J. Auerbach ed., 1988). 
for the corporation, leading to expanded opportunities for its employees. ${ }^{256}$

It is very hard to decide this question in the abstract. The answer differs from corporation to corporation, from time to time, and from one type of decision to another. An attempt to sort through the issue in detail would go way beyond the scope of this article, and would most likely be indeterminate in any case.

One approach would be to look to the leading practical advocates of employee interests, and ask what side they are taking in the battle over corporate governance. The main professional advocates of employee interests are unions, which represent millions of American employees. Those unions are involved in the corporate governance battle via political lobbying and, most visibly, via the actions of union pension plans. Union pensions have been leading advocates in the battle for greater shareholder power. ${ }^{257}$ Union pensions led the campaign for proxy access bylaws that led to the current re-thinking of proxy access. ${ }^{258}$ There is some concern that greater shareholder power will lead to special interest abuse by unions. I have already briefly argued why that is unlikely, ${ }^{259}$ but from a stakeholderist point of view, strengthening the voice of employee advocates somewhat would not be a bad thing at all.

At least two caveats apply to this point. First, on at least some matters unions do seem to have sided with directors and officers against shareholders. For instance, corporate constituency statutes and other antitakeover statutes seem to have gotten at least some union support, although their main impetus has usually been managers. ${ }^{260}$ Second, union pension managers may not take into account the full interest of union members as employees. Indeed, their fiduciary duties require them to consider the interests of members as holders of shares in the plans. Still, the support for limiting executive compensation and reforming corporate governance to lessen managerialism seems to come from the broader union movement, not just from union pension managers.

I thus tentatively conclude that an advocate of employee interests should applaud the proposed greater use of bylaws to enhance shareholder voice. Of the two leading sorts of proposals we have considered, proxy-access bylaws seem more clearly defensible for employee advocates. Indeed, employee advocates in corporations where employees have a decent ownership share could conceivably even try to use such bylaws to give employees some seats on the board. ${ }^{261}$ Poison pill bylaws are rather more problematic because hostile

256. See Bebchuk, supra note 220.

257. See Schwab \& Thomas, supra note 225.

258. See Staff Report, supra note 20.

259. See supra notes $225-26$ and accompanying text.

260. See Jonathan D. Springer, Corporate Constituency Statutes: Hollow Hopes and False Fears, 1999 ANN. SURV. AM. L. 85, 95-96 (1999).

261. Occasional shareholder proposals do suggest such bylaws. See, e.g., Int'l Bus. Machs., SEC No-Action Letter, 1992 SEC No-Act. LEXIS 1135, at *6-7 (Dec. 5, 1992) (reproducing board 
takeovers have been a controversial topic, and at least some do seem to threaten employee interests. Still, the support of union pensions for such bylaws persuades me that those supporting a stakeholder approach should approve of such bylaws as well, or at least have no strong reason to oppose them. ${ }^{262}$

\section{Statutory Interpretation Revisited}

At the beginning of section III I noted that one can draw on many types of sources in considering how to interpret a statute: statutory text, legislative history, related judicial interpretations, and policy analysis. ${ }^{263}$ The scope of the bylaw power is a fascinating case of statutory interpretation because there are strong arguments on both sides of the issue at each of these levels. We have seen a tension between granting boards broad authority and using shareholder voting to constrain the opportunism that sometimes springs from that authority.

There is at least some support for the corporate governance/ordinary business distinction. That is, bylaws that deal with matters of general corporate governance should be allowed, while those dealing with ordinary business matters should not be allowed. The analysis also provides some, though lesser, support for the procedure/substance distinction, namely, bylaws dealing with procedure are valid while those dealing with substantive matters are less likely to be valid. There is also some support for both more expansive and more narrow interpretations of the bylaw power, but this middle interpretation seems to emerge as the best solution. The statutory analysis also suggests, though, that before moving to apply this general distinction, one should first look to more specific statutory provisions and see if they answer the question one way or the other for specific bylaws.

Applying this general analysis to the two main kinds of bylaws we have been considering, proxy access and poison pill bylaws, leads to somewhat different specific analyses. Statutory text, case law, and policy all tend to suggest that proxy access bylaws are valid.

Things are murkier for poison pill bylaws. Although the general corporate governance/ordinary business analysis from the statutory text suggests their validity, the specific provisions of section 157 and 151 of the Delaware law rather strongly point to such bylaws being invalid. Neither the case law nor the

representation proposal of Pedro Del Compare). Of course, persuading a majority of shareholders to approve such a bylaw will not be easy, to say the least.

262. One can also ask how an expansive shareholder bylaw power would affect other corporate constituencies. Probably of most interest, besides employees, would be creditors. The issue for creditors resembles that for employees. On the one hand, hostile takeovers may damage the pre-existing creditors of a target company by creating new debt, thus increasing the chances the company will not be able to repay its existing debt. On the other hand, entrenched managers pursuing private interests may hurt creditors as well as shareholders and employees. Which of these effects predominates is hard to determine in general, and presumably varies from corporation to corporation, and sometimes even over time for the same corporation.

263. See supra note 34 and accompanying text. 
policy analysis favors poison pill bylaws quite as strongly as proxy access bylaws, but both do on the whole favor poison pill bylaws.

This leaves us with a tougher judgment call to make in the case of poison pill bylaws. If one is a dynamic statutory interpreter, ready to rely heavily on policy analysis à la William Eskridge or Richard Posner, ${ }^{264}$ then one should be willing to interpret one's way around the embarrassment of section 157 and find such bylaws valid. As a moderate textualist, I feel more constrained than that by the text, so I face more of a dilemma. All told, I believe that the Delaware courts should hold that poison pill bylaws are valid. The section 157based textual argument is murky enough, and the policy case in favor of such bylaws is strong enough, that the policy argument persuades me.

\section{THE SEC AND SHAREHOLDER PROPOSALS}

For bylaws to be an effective tool for shareholders interested in enhancing controls over boards, favorable state court decisions on the validity of shareholder bylaws affecting board authority are not enough. Shareholders who would like to propose such bylaws must be able to present them for a shareholder vote at relatively low cost. Since most shareholders in public corporations always have the option of selling, ${ }^{265}$ and given the free rider temptation we have discussed, ${ }^{266}$ if the costs of proposing and advocating a bylaw are at all large, shareholders will not propose them. Even the threat of a shareholder bylaw will rarely be credible.

In most public corporations this is a big hurdle. Simply mailing information about a proposal to all shareholders is quite expensive. Most shareholders do not attend annual meetings; instead, they vote by proxy. Soliciting proxies is costly, both because of the large number of shareholders, and also because of the SEC's extensive legal regulation of proxy solicitations. ${ }^{267}$ Indeed, except where a shareholder seeks to take over the corporation and buy a controlling share of stock (which can be quite lucrative), it will almost never be worth it for shareholders to engage in their own proxy solicitations to pass a bylaw amendment.

The only way that bylaws can be a practical tool in public corporations is if shareholders are able to use the corporation's own proxy and proxy statement to solicit support for their bylaw proposals. The problem with that, though, is that the board controls what goes in to the proxy and proxy statement, and if the

264. See William N. ESKRIDGE, JR., DYNAMIC STATUTORY INTERPRETATION (1994); Richard A. Posner, Statutory Interpretation-In the Classroom and in the Courtroom, 50 U. CHI. L. REv. 800 (1983).

265. I say "most" because some mutual funds engage in indexing which may, for instance, require them to hold shares in all companies included in the S\&P 500 index.

266. See supra text accompanying note 221.

267. See Rules 14a-1 through 14a-15; Eisenberg, supra note 115. 
bylaw is aimed at reining in a recalcitrant board, that board is unlikely to allow shareholders to use the company's proxy of its own goodwill.

Enter Rule 14a-8. This rule requires that under certain circumstances companies must include shareholder proposals in their proxy and proxy statement. Shareholders would like to be able to use Rule $14 a-8$ to propose bylaw amendments. The process is cheap and simple enough that at least sophisticated investors, particularly institutional investors, will be able to use it fairly readily. Thus, bylaw amendments can become a practical tool of shareholder control over boards only if the SEC interprets Rule $14 \mathrm{a}-8$ to allow shareholders to use it to propose bylaws.

As it stands, staff interpretation of several provisions of Rule 14a-8 often blocks shareholder bylaw proposals. However, a few simple and highly plausible changes in staff interpretation would remove the obstacles. To see how, we must look at how Rule 14a-8 works.

Shareholders who want a proposal included in a company's proxy must jump through some procedural hoops. They must show that they have held an adequate number of shares for a long enough time. ${ }^{268}$ They must submit the proposal early enough, ${ }^{269}$ and the proposal may not be too long, including its supporting statement. ${ }^{270}$ Either the shareholder or a representative must attend the meeting. ${ }^{271}$ These procedural requirements are not very tough.

If a shareholder jumps through all of the required procedural hoops, then the company must include the proposal in its proxy and proxy statement unless it falls within one or more of thirteen listed exceptions. ${ }^{272}$ It is several of these exceptions that cause problems for bylaw proposals. The three exceptions of most concern are:

the bylaw is improper under state law; ${ }^{273}$

the bylaw relates to the company's ordinary business operations; ${ }^{274}$ and the bylaw relates to an election. ${ }^{275}$

We shall look at each of these exceptions, asking both how the SEC staff interprets them and how it should interpret them as applied to bylaw amendments of the type we have been discussing.

\section{A. Proposals that Are Improper Under State Law}

Rule 14a-8(i)(1) allows companies to exclude a proposal if it "is not a

268. See Rule 14a-8(b)

269. See Rule 14a-8(e).

270. See Rule 14a-8(d).

271. See Rule 14a-8(h).

272. See Rule 14a-8(i).

273. See Rule 14a-8(i)(1).

274. See Rule 14a-8(i)(7).

275. See Rule 14a-8(i)(8). 
proper subject for action by shareholders under the laws of the jurisdiction of the company's organization."276 This basis for exclusion is part of the intricate balancing of state and federal law that goes on in this area. Over the years the SEC decided that proposals which merely suggested that the board do something rarely violate state law; it is only binding proposals which may, depending upon the subject matter, cause a problem. The SEC will thus rarely treat proposals as excludable on this ground if the proposals are merely precatory. Indeed, the SEC has built this understanding into a note to the rule. ${ }^{277}$

This has led to a proliferation of precatory proposals. These are rather an odd duck in corporate law. For one thing, boards are free to ignore them even if the proposals pass, and boards frequently do so. It is not clear whether precatory proposals do much to help shareholders confronting a recalcitrant board, although presumably they do at least have some shaming power. The impact can be more material than that: in some circumstances, ignoring a successful precatory proposal may send a bad signal, leading to a drop in share price. Still, precatory proposals are generally only a weak tool. Moreover, they have only a shadowy presence in state law. Nothing in state law seems to forbid precatory proposals, but nothing seems to provide for them either. They are a creation of SEC interpretation, a fact which occasionally raises irritated commentary from state decision-makers.

The weak effect of precatory proposals motivated shareholder activists to seek out more powerful tools, which led to the bylaw amendment proposals that are the topic of this paper. Because bylaw proposals are mandatory, the SEC will take a much closer look at the improper under state law ground for exclusion, and companies will typically argue for exclusion on this basis when presented with a binding shareholder proposal. As section III made clear, the status of bylaw proposals that arguably limit board authority, including proxy access and poison pill bylaws, is unclear under state law. Few states have either clear statutes or definite judicial interpretations that settle the matter. Quite legitimate arguments exist on both sides of the question.

What can, does, and should the SEC staff do when presented with a bylaw whose state law validity is unclear and the company argues for exclusion on grounds of invalidity under state law? There are three basic possibilities: the SEC can say that the company may not exclude the proposal on this ground, that it may exclude on this ground, or that the staff is unwilling to take a position on whether the proposal is excludable or not.

The SEC staff has taken each of these positions at different times on various corporate governance bylaw proposals. It is not always easy to discern

276. Rule 14a-8(i)(1). Rule 14a-8(i)(2) is similar, allowing exclusion of a proposal if it "would, if implemented, cause the company to violate any state, federal, or foreign law to which it is subject."

277. See Note to paragraph (i)(1). 
a clear pattern, and it would appear that the staff has changed tack at several points. In the early nineties the staff seems to have been more inclined not to permit exclusion of governance bylaws, sustaining proposals involving shareholder representative committees, ${ }^{278}$ employee selection of directors, ${ }^{279}$ confidential voting for directors, ${ }^{280}$ and board independence requirements. ${ }^{281}$ However, at the same time the staff allowed companies to exclude bylaw proposals involving shareholder representative committees that specified that the board could not amend the bylaws. ${ }^{282}$ Starting in 1999 the staff started declaring in many letters that it will not express any view with respect to this ground of exclusion where there is no compelling state law precedent. ${ }^{283}$

The practical effect of this third position is a bit tricky. A no-action letter has very limited binding legal effect. It only prevents the SEC from taking action against that company on that particular set of facts, assuming that the facts as the company has stated them are correct. The SEC can always change its mind in the future, and private parties can go to court even in the particular case covered by the no-action letter. Moreover, even if the SEC does not agree that a proposal can be excluded, a company can always try to go ahead and exclude anyway-the SEC may not take action, and even if it does, the company can go to court and try to get a judge to side with it over the agency. Nonetheless, companies almost never exclude a proposal when the staff has rejected a no-action request, and shareholders rarely go to the trouble and expense of going to court where the SEC has granted a no-action request. What happens when the staff does not take a position either way? According to the leading analysis of no-action letters:

The subtle change of position by the staff on its burden of proof rule-who bears the risk of state law uncertainty-has and will have major consequences to proponents of mandatory proposals: exclusion rather than inclusion. The company is now free to omit the proposal in its mandatory form, and the proponent is forced to either institute suit in the federal district court to compel inclusion or to drop the mandatory aspect of its proposal.

If the staff has taken no position, it remains legally possible that the SEC

278. See Exxon Corp., SEC No-Action Letter, 1992 SEC No-Act. LEXIS 284 (Feb. 28, 1992).

279. See Int'l Bus. Mach. Corp., SEC No-Action Letter, 1992 SEC No-Act. LEXIS 315 (Mar. 4, 1992).

280. See Sears, Roebuck \& Co., SEC No-Action Letter, 1992 SEC No-Act. LEXIS 375 (Mar. 16, 1992).

281. See Louisiana-Pacific Corp., SEC No-Action Letter, 1992 SEC No-Act. LEXIS 554 (Mar. 12, 1992). For a good overview with more detailed descriptions of the no-action letters, see ROBERT J. HAFT, ANALYSIS OF KEY SEC NO-ACTION LETTERS $§ 10: 18$ (2003).

282. See Pennzoil Co., SEC No-Action Letters, 1993 SEC No-Act. LEXIS 304 (Feb. 24, 1993, Mar. 22, 1993); Radiation Care, Inc., SEC No-Action Letter, 1994 SEC No-Act. LEXIS 841 (Dec. 22, 1994).

283. See Cmty. Bancshares, Inc., SEC No-Action Letter, 1999 SEC No-Act. LEXIS 426 (Mar. 15, 1999); E. Enters., SEC No-Action Letter, 1999 SEC No-Act. LEXIS 270 (Feb. 17, 1999); Union Carbide Corp., SEC No-Action Letter, 1999 SEC No-Act. LEXIS 145 (Feb. 5, 1999).

284. HAFT, supra note 281 , at 254. 
could take action if the company chooses to exclude. However, it would seem highly unlikely that the SEC would do so, hence Haft's conclusion as to the practical effect of the take-no-position response.

The SEC says very little to justify its position in no-action letters. The following statements are about the best I can find. In a letter in which the staff said it did not agree that a bylaw proposal that would force the board to terminate defensive measures to certain tender offers unless the shareholders approved continued opposition, the SEC letter said:

The staff notes in particular that whether the proposal is an appropriate matter for shareholder action appears to be an unsettled point of Delaware law. Accordingly, the Division is unable to conclude that rule $14 a-8(\mathrm{c})(1)^{285}$ may be relied upon as a basis for excluding that proposal from the Company's proxy materials. ${ }^{28}$

In a letter in which the staff refused to take a stance, the letter said:

There appears to be some basis for your view that Community Bancshares may exclude the Hanson proposal under rule 14a-8(i)(1). This view is based on the opinion of Waller Lansden Dortch \& Davis that a bylaw provision authorizing the expenditure of corporate funds, effected by shareholders without any concurring action by the board of directors, is inconsistent with Section 141(a) of the Delaware General Corporation Law unless otherwise provided in the company's certificate of incorporation or the Delaware General Corporation Law. Accordingly, we will not recommend enforcement action to the Commission if Community Bancshares omits the Hanson proposal from its proxy materials in reliance on rule 14a-8(i)(1).

Which approach to uncertain state law makes more sense? On its face, the take-no-position approach shows a fitting sense of humility. State courts, not SEC staffers, have the responsibility of interpreting state law, and state judges are likely to be more expert on that law, particularly in the case of Delaware. Therefore, doesn't it make sense for the SEC to admit its ignorance on state law and not take a position on matters where significant controversy exists, and where both sides have good arguments?

It would appear that way, but appearances can be deceiving. Remember the practical effect of the take-no-position approach: companies will exclude the proposals. Remember, too, the limits of shareholder willingness to bear costs in this area. If companies choose to exclude proposals, the shareholders could decide either to fight the exclusion in court or to prepare their own proxy and proxy statement. However, outside of a takeover bid, shareholders will rarely be willing to take on the costs of either of those decisions. Instead, they will let the proposal drop, or perhaps modify it to a precatory proposal.

Consider then the practical effect of the staff's decision to take no position: companies exclude such proposals, and shareholders do not pursue them. Hence, the proposals do not pass. But if the proposals do not pass, there is no way for boards to challenge questionable bylaws in state court. As a result, we

285. The numbering at the time of the present Rule 14a-8(i)(1).

286. PLM Int'I Inc., SEC No-Action Letter, 1997 SEC No-Act. LEXIS 575 (Apr. 28, 1997).

287. Cmty. Bancshares, SEC No-Action Letter, 1999 SEC No-Act. LEXIS 426 (Mar. 15, 1999). 
do not get any further state court precedents on point. Hence the state law uncertainty remains, and hence boards in the future will be able to continue excluding bylaw proposals. The take-no-position response is thus devastating to the practical usefulness of bylaws.

It is also far less humble and deferential to state courts than it appears. By keeping such bylaws from a vote, it prevents state courts from considering the validity of bylaws. Didn't it seem strange, in our discussion of Delaware precedent, that on this interesting, practically important, and rather fundamental point of corporate law, in the leading corporate law jurisdiction, there was so little relevant precedent? The SEC's willingness to allow companies to exclude bylaw proposals goes a long way to helping explain that lack of precedent.

It would be far better, and far truer to the principles of federalism, for the SEC staff to refuse to agree that companies may exclude proposals on Rule $14 a-8(i)(1)$ grounds where significant uncertainty exists as to whether the proposals are valid under the relevant state's law. First, this would allow shareholders to judge whether the proposals are good for their companies. Where a majority approves, but the board remains opposed enough to challenge the resulting bylaw in court, state judges would then be able to pass on the validity of shareholder bylaws. We would thus see much more extensive development of the law in this area, with more expert state judges making decisions with much more detailed reasoning than the SEC staff provides in noaction letters.

Such an approach would allow for more diversity. Shareholders in different corporations could reach different conclusions about what bylaws make sense for their corporations. Judges in different states might also reach different conclusions about what kinds of bylaws are valid. Such diversity is one of the great benefits of federalism. It allows for more variety between corporations, allowing them to tailor rules to their specific circumstances both in the choice of bylaws and in the choice of where to incorporate. ${ }^{288}$ It also allows for more learning, as we can see what effect differing bylaws have. ${ }^{289}$

Note that my suggestion has the effect of putting the burden of proof on the corporation to show that the proposal is invalid under state law. If the corporation does not succeed in convincing the staff that the proposal is invalid, then the corporation may not exclude on that ground. This distribution of the burden of proof has the further virtue of complying with Rule 14a-8's placing on the company the burden of persuading the staff that a proposal can be excluded. ${ }^{290}$

288. See Brett H. McDonnell, Two Cheers for Federalism in Corporate Law, 30 J. CORP. L. 99 (2005).

289. See id.; Brett H. McDonnell, Getting Stuck Between Bottom and Top: State Competition for Corporate Charters in the Presence of Network Effects, 31 HOFSTRA L. REv. 681 (2003).

290. See Rule 14a-8(g). 
Thus, a small shift in interpretive practice could have a big and positive effect on corporate practice. So long as state law in the relevant jurisdiction remains significantly open to doubt, the staff should refuse to agree that a company may exclude a bylaw proposal as invalid under state law. If the invalidity is clear enough given existing law, of course the staff could allow exclusion. But the staff should put quite a strong burden on the corporation to show that existing law entails that the proposal is invalid.

\section{B. Proposals that Relate to Ordinary Business Operations}

Rule 14a-8(i)(7) allows companies to exclude a shareholder proposal if "the proposal deals with a matter relating to the company's ordinary business operations." 291 The SEC gives two main justifications for this exclusion. The first it recognizes explicitly as tracking state law: management should be responsible for ordinary business matters because it is just not practical for shareholders to get involved. ${ }^{292}$ The second is to avoid shareholder micromanagement of complex problems. ${ }^{293}$

If the discussion in section III is correct, then the ordinary business basis for exclusion closely tracks the main distinction between corporate governance and ordinary business matters that should guide state courts in determining what sorts of bylaws are valid. We may therefore first want to ask about the relationship between the ordinary-business exclusion and the violates-state-law exclusion, and thus whether the ordinary business exclusion really makes any sense at all.

The relationship between the two bases for exclusion depends on whether a proposal is precatory or mandatory. As we have seen, the SEC almost always treats precatory proposals as not violating state law. Such proposals may still be excludable because they deal with ordinary business, and the staff does frequently exclude precatory proposals on this ground. One might question how much sense that makes. If a proposal is merely advisory, then even if it is beyond the ability of shareholders to adequately decide the matter, the board can just ignore whatever shareholders say. What is the harm of letting shareholders give some advice?

Of more relevance to us is binding proposals. The main way that shareholders can make legally binding proposals is through bylaw amendments. The state law question of whether a matter is a valid topic for the bylaws is very close, if not identical, to the question of whether the matter covers ordinary business operations. I have just argued that where a matter is questionable under state law, the SEC staff should allow that matter to proceed

291. Rule 14a-8(i)(7).

292. See Release No. 34-40018 (May 21, 1998).

293. See id. You might be wondering if these are two distinct justifications. I am. 
to a vote, and if shareholders approve the bylaw, then the board can pursue the matter in state court if it chooses. The same logic applies here.

How have corporate governance matters fared under the ordinary business exclusion? Where the proposal is framed as a bylaw, they run into the problem of the $14 \mathrm{a}-8(\mathrm{i})(1)$ exclusion that we discussed in the previous sub-section. However, where shareholders have framed the proposal as mere advice, that objection goes away, leaving the ordinary business exclusion as the leading source of contention. The SEC's staff has treated most corporate governance matters as not excludable under $14 \mathrm{a}-8(\mathrm{i})(7)$, although there has been some uncertainty and wobbliness as to what counts as a corporate governance matter. ${ }^{294}$ Proposals concerning executive compensation, golden parachutes, and the independence and choice of auditors, for instance, were once excludable, but now are not. ${ }^{295}$ Robert Haft discusses a wide variety of shareholder proposals that arguably touch on corporate governance matters. His discussion shows how the SEC has generally drawn a line that is discernible and sensible in its broad outlines, though certainly rather murky and hard to rationalize or predict near the boundary of the corporate governance/ordinary business distinction. ${ }^{296}$

What about the two specific types of bylaws that are our special concern, poison pills and shareholder access? The SEC has generally held not excludable precatory poison pill proposals that call for the redemption of pill plans. ${ }^{297}$ This agrees with our discussion of pill bylaws under state law, where I argued that such bylaws appear valid under the corporate governance/ordinary business distinction, although more specific provisions of state law may call their validity into question. ${ }^{298}$ As for shareholder access bylaws, the SEC has given relatively little guidance in applying the ordinary business exception to them because, as we shall see shortly, it has generally allowed those proposals to be excluded on a different ground. ${ }^{299}$ Our discussion of shareholder access bylaws under state law suggests that they are a matter of corporate governance, not ordinary business, and hence should not be excluded on this ground.

Thus, although I have questioned whether the 14a-8(i)(7) ordinary business basis for exclusion makes sense, even if one does not jettison it and applies current SEC staff interpretation on the point, this basis should not present a reason for excluding corporate governance bylaws.

294. See HAFT, supra note $281, \S 10: 3$.

295. See id.

296. See id.

297. See id. at 215-16.

298. See supra notes 120-24 and accompanying text.

299. See infra Part V.C. 


\section{Proposals that Relate to an Election}

Rule 14a-8(i)(8) allows a company to exclude a proposal if "the proposal relates to an election for membership on the company's board of directors or analogous governing body." ${ }^{300}$ For most corporate governance bylaws this is not an issue, but for bylaws granting shareholders access to the company proxy and proxy statement for the purpose of nominating director candidates, this ground for exclusion is crucial. Indeed, the SEC's staff has generally allowed companies to exclude shareholder access proposals on this ground, ${ }^{301}$ with an occasional exception. ${ }^{302}$ As we saw above, the Commission staff most recently wobbled on this point with the Disney proposal in late 2004, but its final position there reverted to the standard line of allowing exclusion. ${ }^{303}$ As we saw in the background section, SEC reconsideration of its approach to this basis for exclusion led to the proposal of Rule $14 \mathrm{a}-11 .^{304}$ In thinking about the wisdom of the SEC's current treatment of $14 a-8(i)(8)$, we will also have to consider this rule's relationship with proposed Rule 14a-11.

Rule 14a-11 would impose one regime on all companies in which shareholder access for nominating directors is triggered. ${ }^{305}$ That one-size-fitsall approach has three major disadvantages relative to allowing shareholders to propose company-specific rules in the bylaws. First, a company-specific approach through bylaw proposals would allow tailoring to the specific circumstances of individual companies. Companies differ in many relevant ways: size, number of shareholders, concentration of shareholding, quality of management, vulnerability to takeovers, and so on. The rule for how many shares one must hold, and for how long, in Rule $14 \mathrm{a}-11$ would probably be too hard for some companies and too easy for others. The Rule thus would lack the flexibility that is one of the key advantages of the general enabling approach of American corporate law. ${ }^{306}$

Second, by allowing differing bylaws in differing companies we could in effect perform a large experiment with shareholder proxy access for board elections. The huge debate over Rule $14 \mathrm{a}-11$ revealed large differences over how to best calibrate the rules even among those sympathetic to shareholder access. Making it too hard to nominate shareholders would eliminate most of

300. Rule 14a-8(i)(8).

301. See HAFT, supra note 281, at 224; Merck \& Co., Inc., SEC No-Action Letter, 2004 SEC NoAct. LEXIS 185 (Jan. 25, 2004); Citigroup, Inc., SEC No-Action Letter, 2003 SEC No-Act. LEXIS 160 (Jan. 31, 2003); Unocal Corp., SEC No-Action Letter, 1991 SEC No-Act. LEXIS 246 (Feb. 8, 1991).

302. See HAFT, supra note 281, at 249; Union Oil Co. of Cal., SEC No-Action Letter, 1983 SEC No-Act. LEXIS 1958 (Feb. 24, 1983).

303. See supra notes 31-33 and accompanying text.

304. See supra notes $24-30$ and accompanying text.

305. There are two triggers: if a majority of shareholders votes in favor of being covered by Rule $14 \mathrm{a}-11$, or if at least $35 \%$ of shareholders withhold their vote from a board-nominee for director.

306. See EASTERBROOK \& FISCHEL, supra note 194. 
the gains from shareholder access, but making it too easy to nominate shareholders could lead to an explosion of expensive contested elections, or at least of nuisance nominations. What rules for proxy access best balance these concerns? The best way to answer that question is to allow different companies to experiment with different rules, and learn from their experiences.

Third, allowing bylaw proposals in this area would allow state law on bylaws and proxy access to evolve. We have already discussed some of the benefits of this. ${ }^{307}$ State courts, especially in Delaware, can add their own wisdom on the topic of the proper division of power between shareholders and boards. Moreover, insofar as states differ in how they answer this question, then that creates yet more potential for learning and tailoring, as the choice of where to incorporate will give companies a choice between various options. ${ }^{308}$

In its Staff Report issued as part of the reconsideration of the approach to shareholder proxy access, ${ }^{309}$ the staff considered as one option amending or reinterpreting rule $14 \mathrm{a}-8(\mathrm{i})(8)$ to allow proposals to amend the bylaws to allow shareholders to use the company proxy to nominate directors. The staff noted some of the strengths of this approach, but also noted several concerns. One concern was with whether boards would be forced to respond to shareholder proxy access proposals, i.e., whether such proposals could be binding rather than advisory under state law. ${ }^{310} \mathrm{I}$ have answered above that proxy access bylaws are pretty clearly valid under state law. ${ }^{311}$

A second concern is that "it is unclear whether companies could avoid implementing this type of proposal by amending their governing instruments to require board approval of shareholder nominees." 312 There are two governing instruments that boards might attempt to amend, the bylaws and the certificate of incorporation. The board can amend bylaws on its own in most corporations. $^{313}$ It is an open, and rather puzzling, question in Delaware whether the board may amend a shareholder-passed bylaw where the bylaw on its own terms states that the board may not do so. In states that follow the Model Business Corporation Act, the Act clearly provides that the board may not do so. ${ }^{314}$ The Delaware statutes provide no clear answer, and no case has yet squarely addressed the question, although there are dicta in both

307. See supra notes $288-89$ and accompanying text. For a similar argument as to the benefits of allowing proxy solicitations in this area, see the prepared statement of Jill E. Fisch before the SEC Roundtable Discussion on Proposed Security Holder Director Nomination Rules, available at http://www.sec.gov/spotlight/dir-nominations/fisch03/204.pdf.

308. See McDonnell, supra note 288; McDonnell, supra note 289.

309. See Staff Report, supra note 20.

310. See id. at 29.

311. See supra Part IV.C.

312. See Staff Report, supra note 20 , at 30.

313. See DEL. CODE ANN. tit. 8, § 109(a) (2005) (certificate of incorporation may confer upon board the power to adopt, amend, or repeal bylaws). Most corporations so provide.

314. See MOD. BuS. CORP. ACT $\S 10.20$ (b)(2) (1984). 
directions. ${ }^{315}$ Even if Delaware courts hold that boards have the power to repeal such shareholder bylaws, there are legal and practical limits to that board power. If the board uses the power inequitably, the Blasius line of cases can be invoked to stop such action. ${ }^{316}$ Alternatively, shareholder bylaws may set procedural roadblocks on board attempts to amend corporate bylaws. ${ }^{317}$ Practically, I doubt whether boards would want so blatantly to counter shareholder desires as to repeal a board-limiting bylaw that shareholders had recently passed. The other governing instrument that boards could amend is the certificate of incorporation. This, however, requires shareholder approval. For already-public corporations, amending the certificate in a way that hurts shareholders may be difficult in today's climate of increased shareholder activism. For not-yet-public corporations, there is much debate as to whether the IPO market will adequately price the likely effects of provisions that hurt shareholders. The traditional answer has been that such provisions will be reflected in the offering share price, ${ }^{318}$ although some now question that answer. $^{319}$

The third main concern is the potential for "an array of confusing companyspecific rules." 320 Several considerations suggest this concern is not too worrying. First, the shareholder activists most likely to introduce successful proposals are typically sophisticated and well-informed, generally institutional investors with good legal counsel. Second, in many cases the shareholders seeking to use a nomination procedure will be those who introduced that procedure in the first place. Third, there are a fairly limited number of active shareholders likely to introduce successful proposals, and those shareholders will presumably introduce similar proposals, perhaps with a few variations, at many different companies. Finally, my years in practice taught me that transactional lawyers almost never start writing with a blank page. Even lawyers who have not previously drafted a proposal will use the proposals of others as a model. The likely outcome is thus that there will be some real variety-variety, after all, is essential to the gains from tailoring and learningbut that variety is unlikely to be so great as to lead to a disabling degree of confusion.

315. See Centaur Partners, IV v. Nat'l Intergroup, Inc., 582 A.2d 923, 929 (Del. 1990) (suggesting shareholder bylaw may not prevent later board bylaw from amending or repealing it); Gen. DataComm Indus. v. State of Wis. Inv. Bd., 731 A.2d 818, $821 \mathrm{n} .1$ (Del. Ch. 1999) (appearing to lean toward same position). Contra Am. Int'l Rent A Car v. Cross, No. 7583,1984 WL 8204, at *3 (Del. Ch. May 9, 1984).

316. See supra notes $184-92$ and accompanying text.

317. See Coffee, supra note 4; John C. Coates IV \& Bradley C. Faris, Second-Generation Shareholder Bylaws: Post-Quickturn Alternatives, 56 Bus. LAW. 1323, 1368 (2001).

318. See Jensen \& Meckling, supra note 213.

319. See, e.g., John C. Coates IV, Explaining Variation in Takeover Defenses: Blame the Lawyers, 89 CAL. L. REV. 1301 (2001).

320. Staff Report, supra note 20, at 30. 
Thus, the SEC would be wise to change its approach to Rule 14a-8(i)(8) and allow shareholders to propose bylaws allowing shareholders to nominate directors through the company proxy in specified situations. This would be better than the proposed Rule 14a-11, although it could also be done in addition to proposed Rule 14a-11.

A final technical question concerning the relates-to-an-election exception concerns whether the SEC or its staff may simply re-interpret the current rule or whether the text of the exception needs to be revised in order to require inclusion of shareholder nomination bylaws. The current rule allows exclusion if "the proposal relates to an election for membership on the company's board of directors." 321 At first glance, this language seems to rather clearly cover shareholder nomination bylaws, which relate to elections, thus suggesting that the rule needs to be re-written. However, there is a decent textual argument to the contrary. The current language refers to proposals that relate to an election. A bylaw does not relate to any one specific election. Rather, it sets procedural rules for every board election. The word "an" thus suggests that we can, maybe even should, read the rule to allow exclusion only of proposals that try to specifically influence one particular election, e.g. by proposing a slate of nominees in the proposal itself. This reading of the rule would allow the staff to require the inclusion of shareholder nomination bylaws without revising the rule. I think that it is plausible enough to allow the SEC to act without formal rulemaking, although it would probably be procedurally sounder to amend the rule.

\section{CONCLUSION}

We see that an expansive, although not unlimited, shareholder power to enact bylaws is both plausible under Delaware's statutory scheme and desirable as a policy matter. Shareholder bylaws that set general rules of corporate governance and procedure, such as those concerning poison pill redemption and proxy access, should be valid unless more specific statutory provisions remove a specific matter from the bylaw power. The SEC should revise its interpretation of Rule $14 a-8$ to require boards to include bylaw proposals unless the particular proposal is clearly invalid under state law.

Shareholders and directors have interests that often overlap but sometimes conflict. They are involved in a never-ending project to craft corporate rules that advance their mutual interests and thereby expand the corporate pie, while each side simultaneously tries to grab as much of that pie for itself as it can, even if that sometimes means decreasing the overall size of the pie. That neverending project occurs within individual corporations, within each state, and at the federal level in the SEC, in Congress, and elsewhere. If Delaware and the

321. Rule 14a-8(i)(8). 
SEC follow the suggestions of this paper, shareholder bylaws will not completely redefine this landscape. However, they will give shareholders a new and useful tool, one that should work to increase the size of the pie that American corporate law helps generate. 